\title{
Molecular evidence on the protective effect of ellagic acid on phosalone- induced senescence in rat embryonic fibroblast cells
}

\author{
Maryam Baeeri ${ }^{1}$, Saeideh Momtaz ${ }^{1,2}$, Mona Navaei-Nigjeh ${ }^{1,3}$, Kamal Niaz ${ }^{1,4}$, Mahban \\ Rahimifard $^{1}$, Seyedeh Farnaz Ghasemi-Niri ${ }^{1}$, Nima Sanadgol ${ }^{1,5}$, Mahshid Hodjat ${ }^{1}$, Mohammad \\ Sharifzadeh ${ }^{1,6}$, Mohammad Abdollahi ${ }^{1,4,6}$
}




\begin{abstract}
Salient evidence testifies the link between organophosphorus (OPs) exposure and the formation of free radical oxidants; and it is well accepted that free radicals are one of the basic concerns of senescence. To show the oxidative features of phosalone (PLN) as a key member of OPs, to induce senescence in rat embryonic fibroblast (REF) cells and to demonstrate the beneficial effects of the known antioxidant ellagic acid (EA) in diminishing the PLN-induced toxic effects, the levels of cell viability, oxidative stress markers, inflammatory cytokines, telomerase activity, and the expression of the genes related to senescence were investigated. Our results lend support to the hypothesis that PLN enhances the entire premature senescence parameters of REF cells. This accounts for the mechanistic approval of the role of OPs in induction of senescence in rat fibroblasts. Moreover, incorporation of EA diminished PLN toxicity mainly through suppression of p38 and p53 at gene and protein levels, and tempered the inflammation factors (TNF- $\alpha$, IL-1 $\beta$, IL-6 and NF-אB), which further affected cell division. Analysis of cell cycle showed that the percentage of G0/G1 arrest, in REF cells treated by EA was elevated as compared to control and PLN treated cells.
\end{abstract}

Key words: aging; cell cycle; ellagic acid; inflammatory cytokines; oxidative stress; phosalone; senescence

\begin{abstract}
Abbreviations:
ABC, Avidin-Biotin-Peroxidase Complex; ATM, ataxia-telangiectasia mutated; ATP, adenosine triphosphate; ATR, ATM- and Rad3-Related; BCA, bicinchoninic acid; CDKN1A, cyclindependent kinase inhibitor p21; Ct, Cycle number; DCFH-DA, 2',7'-dichlorofluorescin diacetate; DMEM, Dulbecco's Modified Eagle's Medium; DMSO, dimethyl sulfoxide; DNA, deoxyribonucleic acid; DNA-PK, DNA-dependent protein kinase; DTT, DL-dithiothreitol; EA, ellagic acid; EDTA, ethylene diamine tetra acetic acid; US EPA, United States Environment Protection Agency; FBS, fetal bovine serum; FDA, Food and Drug Administration; FRAP, Ferric reducing antioxidant power; GAPDH, Glyceraldehyde 3-phosphate dehydrogenase; HCl, hydrochloric acid; HRP, horseradish peroxidase; IC50, inhibitory concentration; IL-1 $\beta$, interleukine-1 $\beta$; IL-6, interleukine-6; LD50, lethal dose; LPO, lipid peroxidation; MDA, malondialdehyde; MTT, 3-4,5 dimethylthiazol-2-yl-2,5-diphenyltetrazolium bromide; NF- $\mathrm{B}$, nuclear factor-kappa-B; OPs, organophosphorus; OSRDs, oxidative stress related diseases; PBS, phosphate-buffered saline; PI, propidium iodide; PLN, phosalone; p38, p38 mitogen activated protein kinases; PRAK, p38-regulated/activated protein kinase; PS, phosphatidylserine; PVDF, polyvinylidene fluoride; RB, retinoblastoma; REF, rat embryonic fibroblast; ROS, reactive oxygen species; RT-PCR, Real Time-reverse Transcription Polymerase Chain Reaction; SASPP, senescence-associated-secretoryphenotype proteins; SA- $\beta$-GAL, senescence associated $\beta$ -
\end{abstract}


galactosidase; SDS-PAGE, sodium dodecyl sulfate polyacrylamide gel electrophoresis; TAP, total antioxidant power; TBA, thiobarbituric acid; TBARS, thiobarbituric acid reactive substances; TBS, tris-buffered saline; TGF- $\beta$, transforming growth factor-beta; TMB, 3,3',5,5'tetramethylbenzidine; TNF- $\alpha$, tumor necrosis factor-alpha; TP53,Tumor protein; TPTZ, tri (2pyridyl)-s-triazine; TTM, total thiol molecules; TUMS, Tehran University of Medical Sciences; X-gal, 5-bromo-4-chloro-3-indolyl- $\beta$-d-galactopyranoside; WHO, Word Health Organization. 


\section{Introduction}

Cellular senescence is defined as a phenomenon by which normal diploid cells cease to divide. Telomerase shortening leads to replicative senescence that ultimately triggers deoxyribonucleic acid (DNA) damage responses. Elevation of reactive oxygen species (ROS), activation of oncogenes and cell-cell fusion, can also cause DNA damages independent of telomerase shortening; thus cells might undergo senescence. It has been proven that both extrinsic and intrinsic factors form ROS. Among these, environmental toxic agents, and pesticides, in particular, appeared to be bolder. The morphology, physiology, and gene expression of senescent cells are specifically changed, while cells are metabolically active but unable to express genes required for cellular proliferation (Campisi, 2001; Narita et al., 2003).

Environmental toxicants raise the number of age-related diseases and alter human health in both embryonic and adult stages (Hodjat et al., 2015; Rezvanfar et al., 2016). The world health organization (WHO) task group has lately estimated that the number of pesticide poisoning may climb to three million cases and result in more than 250,000 deaths (WHO, 2006). Organophosphorus pesticides (OPs), categorized as a class of phosphorus chemicals, are used to control pests in agriculture; and their use is increasing all over the world. Phosalone (PLN) $(O, O$ diethyl-S-(6-chloro-2-oxobenzoxazolin- 3-yl-methyl)-phosphorodithioate) and diazinon are the most common agricultural pesticides used for pest control (WHO, 2006). The average daily intake of PLN from diet estimated by the US food and drug administration (FDA) total diet study was $<0.0001 \mu \mathrm{g} / \mathrm{kg}$ body weight-day for both infants and adults (US EPA, 2001). In addition, acute and chronic exposure assessment of PLN has been reported as 0.000049 and 0.000001 $\mathrm{mg} / \mathrm{kg} /$ day, respectively in US (US EPA, 2001). Additionally, it has been demonstrated that the toxicity of PLN (lethal dose 50\% (LD50) is notably lower from the dermal route than the oral 
route in rats with LD50s of $120 \mathrm{mg} / \mathrm{kg}$ and 1,500 mg/kg, respectively (Morris and Lee, 1984; Pasquet et al., 1976).

A common mechanism of OPs is associated with the alteration of ROS and lipid peroxidation (LPO). Excessive concentration of ROS generates oxidative stress. OPs contamination alters the antioxidant defense mechanisms (Ghasemi-Niri et al., 2016; Maqbool et al., 2015; Bahadar et al., 2014). OP-induced oxidative stress leads to depletion of the mitochondrial energy (adenosine triphosphate, ATP), mitochondrial or extra mitochondrial production of free radicals, induction of the proteolytic enzymes, DNA fragmentation leading to apoptosis, alteration of the enzymatic antioxidants, LPO and incense of the LPO by-products (Soltaninejad and Abdollahi, 2009; Mostafalou and Abdollahi, 2013, 2016).

Increased level of ROS resulted in the stimulation of some inflammatory factors in the nucleus through particular genes (Kregel and Zhang, 2007; Abdollahi et al., 2005; Kajbaf et al., 2007; Najafi et al., 2009). In addition, ROS facilitate shortening of the telomere (Von Zglinicki, 2002) and disrupting the DNA, both of which trigger senescence. In this way, the sensor kinases (ataxia-telangiectasia mutated/ATM-and Rad3-Related, DNA-dependent protein kinase) (ATM/ATR, DNA-PK) are activated and then DNA damage occurs and ultimately cell cycle arrest is induced via checkpoint proteins, Tumor protein $\left(\mathrm{TP}_{53}\right)$ and the cyclin-dependent kinase inhibitor p21 (CDKN1A) (Di Fagagna et al., 2003). Lee et al. (1999) showed that the potential of primary cells to induce senescence was influenced by oxygen level, thus not only ROS but oxygen tension is also involved in senescence. ROS may disrupt two canonical pathways interfering senescence; p53-p21 and p16-RB (retinoblastoma) signal transduction systems (Iwasa et al., 2003). ROS has been documented to regulate cell proliferation and death by internal cues 
(p53-mediated), external cues transforming growth factor-beta (TGF- $\beta$-mediated) and immunogenic signals tumor necrosis factor-alpha (TNF- $\alpha$ ) (Li et al., 2002).

ROS cause the activation of p53 and transcription of $\mathrm{p} 21$, and thereby leading to senescence (Passos et al., 2010). Increased expression of p21 has been shown to increase ROS production, therefore the interaction between p21 and ROS is involved in mediating the DNA damage and senescence which is mainly proportional to cell type (Fitzgerald et al., 2015). In another instance, ROS activated MINK-p38-PRAK pathway, of which the mitogen activated protein kinases (p38) activates p53 and mediates senescence. In turn, p38-activated protein kinase (PRAK) is stimulated to induce senescence (Han and Sun, 2007).

ROS may directly activate certain redox-sensitive pathways linked to senescence. The activation of redox-sensitive transcriptional factors leads to upregulation of pro-inflammatory gene expression (Kregel and Zhang, 2007). ROS activate TNF- $\alpha$ and other inflammatory factors

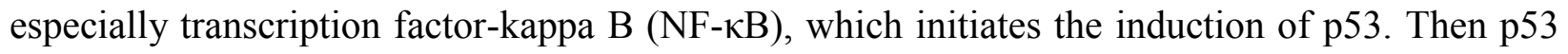
facilitates pathways leading to either senescence via the activation of p53-p21 or release of cells from the stress made by G1/S arrest (Serrano et al., 1997).

Antioxidant compounds can reduce oxidative stress related diseases (OSRDs) and cellular damage against free radicals via annihilated oxidative components (Saeidnia and Abdollahi, 2013b; Manayi et al., 2014). Phenolic phytochemicals, such as ellagic acid (EA) (2,3,7,8tetrahydroxy-chromeno[5,4,3-cde]chromene-5,10-dione) are important constituents of the daily nutrition and are partly responsible for the beneficial health effects against oxidation-linked chronic diseases. Literature review showed the lack of adequate information about the bioavailability, daily dietary intake and pharmacokinetics of EA in humans. However, Seeram et al. (2004) reported that EA was found without any structural modification in human plasma at its 
maximal concentration $1 \mathrm{~h}$ upon pomegranate juice consumption. It is believed that EA offsets the negative effects of oxidative stress by direct action as an antioxidant or by activating/inducing cellular antioxidant enzyme systems (Vattem and Shetty, 2005). El-Shitany et al. (2014) reported that EA can potentially protect DNA from ROS, and chelation of the metal ions. Consequently, it reduces DNA and cell damages. In vitro studies have revealed that EA exerts growth-inhibiting and apoptosis-inducing cytotoxicity on various cancers (Bisen et al., 2012; Weisburg et al., 2013; Li et al., 2005). Recently, Ghasemi-Niri et al. (2016) reported that EA can protect colon cells from toxicity and cell damage due to PLN induction/exposure. EA exhibits a dual activity predominantly as antioxidant, although asserts as pro-oxidant too (Zhang et al., 2014). This extraordinary property of EA is conditional to cell type (Saeidnia and Abdollahi, 2013a).

Embryonic fibroblasts as well as embryonic stem cells are the cells of choice for the assessment of developmental toxicity and have been implicated in many classical toxicology tests. It was demonstrated that any changes in their normal function could affect the regenerative potential of organs, leading to the appearance of age related disease and acceleration of the aging process (Hodjat et al., 2015). Therefore, study of the harmful effects of pesticides and protective effects of anti-aging agents on embryonic cells would be of high importance due to their regenerative role in the body. Primarily, this study presents the first statement on the deep molecular and cellular investigation of the age related oxidative and inflammatory parameters of rat embryonic fibroblast (REF) cells affected by PLN as a pro-oxidant agent and EA as a well reputed antioxidant. Indeed, the main aim of the current study was to explore two hypotheses; the cytotoxicity of PLN and its ability to initiate senescence in REF cells, and the protective aspects of EA to compensate or affect the key indicators of senescent cells. 


\section{Materials and Methods}

\subsection{Chemicals}

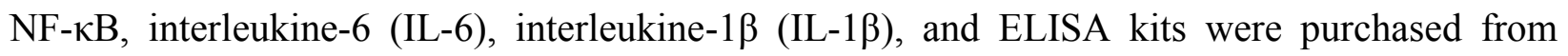
Bender MedSystems Inc. (Vienna, Austria). Senescence $\beta$-galactosidase staining kit was from Cell Signaling Technology (Mississauga, ON, Canada). Rat specific $\beta$-galactosidase kit was purchased from (Cusabio, China). Antibodies for the detection of NF-kB/p65 (F-6), p38 $\alpha$ (C-20), RB (IF8), p53 (FL-393), goat anti-rabbit IgG-FITC and goat anti-mouse IgG-PE were obtained from Santa Cruz Biotechnology (Santa Cruz, CA). Dulbecco's modified eagle's medium (DMEM), fetal bovine serum (FBS), 3-4,5 dimethylthiazol-2-yl-2,5-diphenyltetrazolium bromide (MTT), rat TNF- $\alpha$ ELISA kit, bovine serum albumin (BSA), EA, ethylene diamine tetra acetic acid (EDTA), 2',7'-Dichlorofluorescin diacetate (DCFH-DA), DL-dithiothreitol (DTT), dimethyl sulfoxide (DMSO), 4-(2-hydroxyethyl)-1-piperazineethanesulfonic acid (HEPES), RNase solution and propidium iodide were from Sigma-Aldrich (Munich, Germany). PLN was obtained from local pesticide manufacturing companies (Agroxir). Thiobarbituric acid (TBA), trichloroacetic acid, n-butanol, tri (2-pyridyl)-s-triazine (TPTZ), hydrochloric acid ( $\mathrm{HCl})$, malondialdehyde (MDA) and ferric chloride $\left(\mathrm{FeCl}_{3}-6 \mathrm{H}_{2} \mathrm{O}\right)$ were purchased from Merck Chemical Co. (Germany).

\subsection{Cell Culture}

The isolation and culture of primary REFs were conducted with requisite approval from the Institutional Review Board of Tehran University of Medical Sciences (TUMS), Iran with ID of IR.TUMS.REC.1394.2010. 
Healthy adult female albino rats of the Wistar strain, weighing 180-200 grams, were supplied by the Animal Breeding House of Faculty of Pharmacy of TUMS. Animals were maintained at the animal standard care facility under controlled temperature $\left(23 \pm 1^{\circ} \mathrm{C}\right), 12 \mathrm{~h}$ light/dark cycle, $55 \pm$ $10 \%$ humidity and ad libitum feed. The rats were kept for induction of pregnancy and the primary MEFs were isolated using the standard protocol (Yusuf et al., 2013). The E12.5-13.5 pregnant rats were anesthetized with pentobarbital $50 \mathrm{mg} / \mathrm{kg}$. The uterine horns, placenta, heads, limbs and gonads, tails and other visceral mass were detached. The embryos (12-12.5 days) were further separated and washed with phosphate-buffered saline (PBS) containing antibiotics. The cells were isolated mechanically (chopping the tissue into fine pieces) and by way of enzymatic degradation (digestion of tissue with $0.25 \%$ EDTA). The isolated tissue was supplemented with appropriate culture medium and pipetted recurrently to get a single cell suspension. The cells were cultured in T-75 flasks until nearly confluent. Cells were maintained at $37{ }^{\circ} \mathrm{C}$ in a humidified atmosphere with $5 \% \mathrm{CO}_{2}$. REFs were used at passages (P3) since the aging was induced in the cells by PLN during the trial (Yusuf et al., 2013). At least three pregnant rats were used for isolation of REFs.

\subsection{Toxicity of PLN on REFS}

Prior to perform the experiments, based on the previous studies (Altuntas et al., 2003; Fulton and Key, 2001), REF cells $\left(1 \times 10^{5}\right.$ cells/well $)$ were cultured in combination with different concentrations of PLN $(0.01,0.1,1$ and $10 \mathrm{mM})$ for $24 \mathrm{~h}$ at $37^{\circ} \mathrm{C}$ and $5 \% \mathrm{CO}_{2}$ humidified atmosphere. Afterwards, the cytotoxicity study was conducted using MTT assay. In addition, probit regression analysis (StatsDirect, Version 3.0.183) was used to estimate the median inhibitory concentration (IC50) of PLN. 


\subsection{Treatment conditions and experimental groups}

After determining the IC50 of PLN, the experimental samples were categorized as the following groups and were utilized for the assays: (a) control; only REF cells in medium; (b) REFs with PLN at the concentration of $1 / 10$ of its IC50 $(0.11 \mathrm{mM})$ (based on data obtained from section 2.3, various experiments were conducted and the one-tenth of PLN IC50 value was found to be the most effective concentration and thus selected as the effective dose for this study); (c) REFs + EA (the highest concentration of EA (1000 nM) was used as a positive control); (d) REFs + PLN $(0.11 \mathrm{mM})+$ EA $(1 \mathrm{nM}) ;(\mathrm{e})$ REFs + PLN $(0.11 \mathrm{mM})+\mathrm{EA}(10 \mathrm{nM}) ;(\mathrm{f})$ REFs + PLN $(0.11 \mathrm{mM})$ + EA (100 nM); (g) REFs + PLN (0.11 mM) + EA (1000 nM). For protective treatment, optimization of the dosage was performed by simultaneous treatment of PLN-induced cells with logarithmic concentrations $(1,10,100$ and $1000 \mathrm{nM})$ of EA for $24 \mathrm{~h}$ to ascertain the most efficacious dose. These concentrations of EA were preferred based on previous studies (Han et al., 2006; Muñoz-Muñoz et al., 2009).

\subsection{REFs Viability Assay}

The viability of cultured cells assessed using MTT assay. After $24 \mathrm{~h}$ of incubation, the cells were washed twice by phosphate buffer. Subsequently, $50 \mu \mathrm{L}$ of MTT solution was added and reincubated for $3-4 \mathrm{~h}$ at $37^{\circ} \mathrm{C}$ and $5 \% \mathrm{CO}_{2}$ humidified atmosphere. Finally, $150 \mu \mathrm{L}$ of DMSO solution was added and the absorbance was determined at $570 \mathrm{~nm}$ by ELISA reader. The viability of the treatment groups was reported as the percentage of controls which put on $100 \%$.

\section{6. $\beta$-Galactosidase Assay}




\subsection{1. $\beta$-Galactosidase Cytochemical Assay}

Senescence-associated $\beta$-galactosidase activity is widely used as a biomarker for assessing replicative/induced senescence in mammalian cells. This enzymatic activity was measured by staining cells with the chromogenic substrate 5-bromo-4-chloro-3-indolyl- $\beta$-d-galactopyranoside

$(\mathrm{X}$-gal) at $\mathrm{pH} 6.0$, a reaction condition that suppresses lysosomal $\beta$-galactosidase activity sufficiently to ensure that most non-senescent cells will appear unstained. The senescence galactosidase staining kit was utilized to evaluate the $\beta$-galactosidase activity in REFs, as instructed by the manufacturing company. After different treatments, REFs were washed with PBS twice and then the fixative solution (20\% formaldehyde, $2 \%$ glutaraldehyde in 10X PBS) was added for 10-15 minutes (min) at room temperature. Cells were washed and stained with $\beta$ galactosidase stain, and were allowed to incubate overnight at $37^{\circ} \mathrm{C}$. Cells were observed by phase contrast microscope (Olympus BX51, Japan) and photographed at 200× magnification. Senescent cells were exemplified by the occurrence of bluish green color under the light microscope.

\subsubsection{Quantitative Assay of Senescence Associated $\beta$-Galactosidase (SA- $\beta$-GAL)}

Rat specific galactosidase kit was used for this assay in accordance with the manufacturer's guidelines. $100 \mu \mathrm{L}$ of both sample and standard were added to the wells and incubated for $2 \mathrm{~h}$ at $37^{\circ} \mathrm{C}$. After exclusion of the liquid, $100 \mu \mathrm{L}$ of biotin-antibody was added to each well and the plates were incubated for $1 \mathrm{~h}$. REFs were washed, $100 \mu \mathrm{L}$ of horseradish peroxidase-avidin (HRP-avidin) was applied to each well and the incubation time was extended for another $1 \mathrm{~h}$. Subsequently, $90 \mu \mathrm{L}$ of 3,3',5,5'-tetramethylbenzidine (TMB) was added to the wells and they 
were re-incubated for $30 \mathrm{~min}$ in dark. At the final step, the stop solution was added and the absorbance was verified at $450 \mathrm{~nm}$ by ELISA reader.

\subsection{Measurement of oxidative stress parameters}

2.7.1. LPO Assay

Thiobarbituric acid reactive substances (TBARS) method is a well-known and typical technique to evaluate LPO (Armstrong and Browne, 1994). The experimental samples were homogenized and $800 \mu \mathrm{L}$ of trichloroacetic acid was added to them, which later were centrifuged at $3000 \mathrm{~g}$ for $40 \mathrm{~min}$. Next, the supernatant $(600 \mu \mathrm{L})$ was mixed with $150 \mu \mathrm{L}$ TBA $(1 \% \mathrm{w} / \mathrm{v})$ and the mixture

was kept in boiling water bath for 15 min followed by addition of n-butanol $400 \mu \mathrm{L}$. After cooling, the optical density was confirmed at $532 \mathrm{~nm}$. The method was set up in our lab (Rahimifard et al., 2015).

\subsubsection{Total Antioxidant Power (TAP) Assay}

Ferric reducing antioxidant power (FRAP) assay is an indication of the antioxidant power of the biological samples (Benzie and Strain, 1996). The reduction of ferric to ferrous ion leads to the formation of a colored ferrous-TPTZ complex at low $\mathrm{pH}$. FRAP values were reported at $593 \mathrm{~nm}$. The method was set up in our lab (Moeinian et al., 2014).

\subsubsection{ROS Assay}

2',7'-dichlorofluorescin diacetate (DCF-DA), a fluorogenic reagent (measures ROS activity within the cells), diffuses into the cell and is deacetylated by cellular esterase to a nonfluorescent compound, which is later on oxidized by ROS into DCF. Thus, ROS assay can be 
conducted via the calculation of the amount of DCF production in the cells. DCF is highly fluorescent and can be detected by fluorescence spectroscopy with maximum excitation and emission spectra of $488 \mathrm{~nm}$ and $529 \mathrm{~nm}$, respectively. In brief, test samples were prepared, homogenized and centrifuged. The supernatant was mixed with buffer assay and DCFH-DA and incubated for $15 \mathrm{~min}$ at $37^{\circ} \mathrm{C}$. Finally, the absorbance changes were proved by ELISA fluorimeter. The method was set up in our lab (Momtaz et al., 2013).

\subsubsection{Assay of total thiol molecules (TTM)}

The amount of total thiol content of a sample usually correlates with its antioxidant status $(\mathrm{Hu}$ 1994. In this study, samples were prepared as mentioned before, then $0.6 \mathrm{ml}$ Tris-EDTA buffer (Tris base $0.25 \mathrm{M}$, ethylene diamine tetra acetic acid $20 \mathrm{mM}, \mathrm{pH} 8.2$ ) was added to $0.2 \mathrm{ml}$ of the samples' supernatants, and they were then vortexed quickly. Samples were mixed with $40 \mu 1$ of 5-5'-dithiobis-2-nitrobenzoic acid (10 $\mathrm{mM}$ in pure methanol) and after $15 \mathrm{~min}$ of incubation at room temperature the plates were centrifuged at $3000 \mathrm{~g}$ for $15 \mathrm{~min}$. The absorbance of the supernatant was recorded at $412 \mathrm{~nm}$ and results were displayed by mean mM. The method was set up in our lab (Bahadar et al., 2015).

\subsection{Flow Cytometry Evaluation of Apoptosis and Necrosis}

This assay was performed to evaluate the protective tendency of EA to either decrease or even halt the apoptotic/necrotic effects of PLN in REF cells. The translocation of the membrane phosphatidylserine (PS) from the inner side of the outer layer is a typical sign of early apoptosis. Annexin $\mathrm{V}$ as a phospholipid-binding protein shows high affinity to bind to PS; and fluorochrome-labeled Annexin V is frequently used to detect the exposed PS and apoptotic cells. 
In a necrotic cell, propidium iodide (PI) as a fluorescent dye, penetrates cell membrane and binds to the chromosomal DNA, while PI is rejected by the membrane of the viable cells. In this study, the percentages of apoptosis and necrosis were measured by ApoFlowEx ${ }^{\circledR}$ FITC kit. To perform this assay, experimental samples were prepared $\left(3 \times 10^{5}\right.$ cells/well $)$, harvested, stained and incubated with $5 \mu 1$ of AnnexinV-FITC and PI for $15 \mathrm{~min}$ at room temperature. G1, S, and G2 phases were determined through flow cytometer (Apogee Flow Systems, Enterprise House, Maxted Road, Hemel Hempstead, Herts, Hp2 7BT, UK) in FL1 (FITC) and FL2 (PI) channels. The procedure was set up in our lab (Rahimifard et al., 2015).

\subsection{Measurement of Inflammatory Cytokines}

\subsubsection{Determination of $T N F-\alpha$}

TNF- $\alpha$ is a potent modulator of immune and inflammatory responses in various cells and its increase indicates an aging icon. The quantity of TNF- $\alpha$ in test samples was examined by a rat specific TNF- $\alpha$ ELISA kit (Bender MedSystem, Vienna, Austria). Test samples and standards were added to the wells containing immobilized antibodies. After washing, biotinylated anti-rat TNF- $\alpha$ antibody and HRP conjugated streptavidin were introduced to each well. Samples were rewashed; TMB and stop solutions were added to the wells respectively. A color change (from blue to yellow) proportional to the TNF- $\alpha$ level was assessed at $450 \mathrm{~nm}$.

\subsubsection{Determination of $I L-1 \beta$}

This assay was conducted to compare the levels of cytokines IL-1 $\beta$ in REF cells after they were exposed to the different concentrations of PLN and EA. The protocol was followed according to the instructions of rat specific IL- $1 \beta$ specific kit. 


\subsubsection{Determination of $I L-6 \beta$}

IL-6 6 is a pro-inflammatory cytokine, secreted to stimulate immune responses and its production is known to be elevated in aged cells/tissues. To determine the IL-6 levels in samples, a rat specific IL-6 ELISA kit was used. Test samples and standards were added to the wells and incubated at $37{ }^{\circ} \mathrm{C}$ for $90 \mathrm{~min}$. Subsequently, biotinylated antibody was added and all the wells were washed with Tris-buffered saline (TBS) buffer three times. After additions of AvidinBiotin-Peroxidase Complex (ABC) working solution, cells were rewashed with PBS and the chromogenic reagent TMB was added and the plates were incubated in the dark. In the final step, the stop solution was applied and the yellow color intensity was measured at $450 \mathrm{~nm}$.

\subsubsection{Determination of $N F-\kappa B$}

$\mathrm{NF}-\mathrm{\kappa B}$ is a protein complex that controls transcription of DNA and is involved in cellular responses to stimuli such as stress, cytokines, and free radicals, with a key role in regulation of the immune responses. The level of NF- $\mathrm{kB}$ in REF cells was determined using a specific transcription factor kit as previously set up in our lab (Esmaily et al., 2011). Biotinylated probe was added into each micro tube containing samples. Then, tubes were vortexed and their contents were transferred to a microtiter plate, which was left for $1 \mathrm{~h}$ on mild agitation. Cells were washed 3 times and the primary antibody (NF-kB) was added to each well for $1 \mathrm{~h}$ incubation. Similar processes were followed until the secondary antibody (HRP) was added. After specific incubation, developing solution was applied indicating the colorimetric reaction. Eventually, stop solution was added and the absorbance was measured at $450 \mathrm{~nm}$. 


\subsection{Expression of $N F-\kappa B / p 65, p 38 \alpha, R B, p 53$ in REFs by Flow Cytometry}

Cells were seeded, treated and collected for the appropriate result of test groups. They were also processed for flow cytometric analysis. Paraformaldehyde (final concentration of 4\%) was applied to the culture medium and cells were fixed for 20 min at $4^{\circ} \mathrm{C}$, following precipitation. Afterwards cells were washed twice in PBS solution and centrifuged at $1200 \mathrm{rpm}$ at $4^{\circ} \mathrm{C}$ for 10

min. $5 \times 10^{6}$ cells were re-suspended and permeabilized through addition of $200 \mu 1$ of Triton X100 ( $0.4 \%$ in PBS). They were then placed adjacent to the samples for $20 \mathrm{~min}$ at room temperature and were removed later by centrifuge; blocking solution (Triton X100 (0.1\%) and BSA (1\%) in PBS solution) was then added for 45 min at room temperature. Optimal concentrations (5 $\mu \mathrm{g})$ of fluorophore-specific mAbs (NF-Kb/p65, p38a, RB and p53) were added to test samples and were then incubated for $1 \mathrm{~h}$ at room temperature. In the next step, samples were washed with PBS and pelleted, subsequently the secondary Abs was added and the resultants were incubated for $2 \mathrm{~h}$ in dark condition.

\subsection{Real Time-reverse Transcription Polymerase Chain Reaction (RT-PCR)}

To investigate the molecular mechanisms of cellular senescence in REFs, the expression levels of $\mathrm{p} 53$ and $\mathrm{RB}$ genes were examined by quantitative RT-PCR. In this regard, test samples were incubated for $24 \mathrm{~h}$ and REFs were trypsinized and centrifuged for $5 \mathrm{~min}$ at $1200 \mathrm{rpm}$ of the cells to pellet formation. The pellets were washed three times with sterile PBS for RNA isolation. Total RNA was extracted from the cultured cells using TRIzol® reagent according to the manual guidelines. The concentration of RNA was quantified by Thermo Scientific NanoDrop 2000c UV-Vis spectrophotometer (Thermo Scientific, USA). The genomic DNA was removed, using DNase-I, RNAse-free kit; on the other hand, cDNA was reverse transcribed using the iScript 
cDNA Synthesis Kit. Primer pairs were used with Glyceraldehyde 3-phosphate dehydrogenase (GAPDH) as the internal control. Quantitative RT-PCR was performed on LightCycler ${ }^{\circledR} 96$ System (Roche) by using the SYBR green master mix (Table 1). Cycle number $(\mathrm{Ct})$ of each reaction was calculated from the amplification curve to determine the relative gene expression by using the comparative cycle threshold method (Schmittgen and Livak, 2008). $2^{-\Delta \Delta C t}$ was used for relative gene expression analysis. All $\mathrm{Ct}$ values calculated from the target genes were adjusted using those from the untreated control cells. The abbreviations, accession numbers, and primers of proteins are shown in table 1.

\subsection{Western Blot Analysis}

Immunoblotting was performed as described previously by Sanadgol et al. (2012). In brief, differentiated cells were washed with ice-cold PBS, homogenized with complete protease inhibitor cocktail (Roche, Mannheim, Germany), centrifuged, and protein levels were estimated according to Bicinchoninic Acid (BCA) protein assay method (Sigma-Aldrich). Total protein (50 $\mu \mathrm{g})$ was resolved in sodium dodecyl sulfate polyacrylamide gel electrophoresis (SDS-PAGE) gels and transferred to polyvinylidene fluoride (PVDF) membranes via electrophoretic transfer system (Bio-Rad, Munchen, Germany). The membranes were blocked and incubated overnight, with specific primary antibodies $(1: 500)$, at $4^{\circ} \mathrm{C}$. Primary antibodies were: rat monoclonal antibodies top, $\mathrm{p} 38, \mathrm{RB}$ and $\mathrm{NF}-\mathrm{\kappa B} / \mathrm{p} 65$ as well as rat monoclonal antibodies to $\beta$-actin to monitor loading. The membranes thoroughly washed with PBS, 0.05\% Tween-20 (PBS-T), and incubated with respective HRP conjugated secondary antibodies $(1: 1000)$ at $4^{\circ} \mathrm{C}$ for $4 \mathrm{~h}$. The blots were exposed to HRP substrate solution (3, 3'-diaminobenzidine and $\mathrm{H}_{2} \mathrm{O}_{2}$ ) for detection of target antigens. After staining, band intensities were quantified using NIH ImageJ 
(http://rsb.info.nih.gov/ij/) software after background subtraction and each lane of protein band density was normalized.

\subsection{Cell Cycle Analysis by PI Staining (Flow Cytometry)}

For cell cycle analysis, REF cells were trypsinized, fixed with ice cold ethanol $70 \%$ and centrifuged at $10000 \mathrm{~g}$ for $5 \mathrm{~min}$. After washing with ice cold PBS, the pellets were redistributed in PI having RNAse. Next, the cells were incubated at room temperature. G1, S, and G2 phases were determined through the flow cytometer.

\subsection{Telomerase Activity}

Telomere length tightly correlates with the level of telomerase activity, which plays a vital role in the determination of aging in cells and tissues. Senescence happens in the absence of telomerase activity that leads to a progressive telomeres shortening. Here, the effect of the samples on telomerase activity was estimated in age induced REFs using TeloTAGGG Telomerase PCR ELISA ${ }^{\text {Plus }}$ (Roche, Germany). The kit is used to control the amplification process and quantify the PCR product formed.

\subsection{Statistical Analysis}

The independent experiments were carried out in 4 repetitions. In this study, data were shown as mean \pm standard error of mean (SEM). One-way analysis of variance (ANOVA) and Tukey's multi-comparison tests were carried out by Stats-Direct version 3.0.183 to determine the statistical difference $(\mathrm{p}<0.05)$ between treated and control groups. Also, the IC50 of PLN and regression were performed with $95 \%$ confidence intervals. 


\section{Results}

\subsection{Determination of IC50 of PLN}

As shown in Fig. 1, the MTT assay was used to calculate the concentration of PLN which could possess $50 \%$ decrease in viability. It was illustrated that the mitochondrial activity of REF cells decreased by increasing the concentration of PLN after $24 \mathrm{~h}$ of exposure in comparison with untreated samples (control group). According to obtained results, the IC50 of PLN was estimated $0.11 \mathrm{mM}$.

\subsection{REFs Viability Assay}

Parallel to the increase of EA, cell viability was raised up dose-dependently in REFs as shown in Fig. 2. EA significantly increased viability in REF cells at $1000 \mathrm{nM}(\mathrm{p}<0.001)$.

\section{3. $\beta$-Galactosidase Cytochemical Assay}

The effect of PLN and EA on $\beta$-galactosidase activity is presented in Fig. 3. REF cells treated with PLN showed a significant rise in the concentration of $\beta$-galactosidase activity as compared with control group $(\mathrm{p}<0.001)$. While REF cells have shown significantly lesser amount of $\beta$ galactosidase content in all PLN + EA treated groups, as compared to PLN group.

\subsection{Oxidative Stress Biomarkers}

The REF cells exposed to PLN alone and/or in combination with EA (at $1 \mathrm{nM}$ ) showed high amounts of ROS and LPO as compared to control group ( $\mathrm{p}<0.001$ and $\mathrm{p}<0.01$ respectively). Certainly, PLN increased ROS production and LPO at 1/10 of its IC50. Furthermore, EA 
significantly attenuated PLN and reduced ROS and LPO in REF cells dose-dependently ( $<<$ 0.001). Likewise, exposure to $1000 \mathrm{nM}$ of EA and PLN significantly enhanced FRAP and the level of total thiols in REF cells ( $p<0.001$ ) (Fig. 4).

\subsection{Flow Cytometry Evaluation of Apoptosis and Necrosis}

Fig. 5 illustrates the percentage of necrotic, apoptotic and viable cells in PLN-induced senescent REF cells. In brief, Q1 represents necrosis (FLTC ${ }^{-} \mathrm{PI}^{+}$), Q2 shows late-apoptosis cells (FLTC ${ }^{+}, \mathrm{PI}^{+}$), Q3 expresses alive cells (FLTC - PI $^{-}$) and Q4 describes apoptosis (FLTC ${ }^{+}$, PI ${ }^{-}$). Obviously in Q3 ( FLTC $^{-}$, $\mathrm{PI}^{-}$), EA group contained the highest level of cell viability (76.6\%) as compared with the other groups. The rate of late apoptotic cells had been lifted up by PLN, comparing with control group. Moreover, population of viable cells swelled significantly by EA at concentrations 100, $1000 \mathrm{nM}$ with constant PLN concentration groups. EA abrogated the PLN apoptotic effects and increased the number of living cells.

\subsection{Measurement of Inflammatory Cytokines}

REF cells exposed to PLN showed high levels of inflammatory cytokines (TNF- $\alpha$, IL-1 $\beta$, IL-6 $\beta$ ) and transcription factor NF- $\mathrm{kB}$ compared to control cells $(\mathrm{A}, \mathrm{B}, \mathrm{C}, \mathrm{D})(\mathrm{p}<0.001)$. EA significantly decreased the level of inflammatory markers in REFs $(\mathrm{p}<0.001)$. In addition, EA showed a protective and stimulating effect in a dose-dependent manner to quench PLN-induced senescence in REFs $(p<0.001)$. The amount of IL- $6 \beta$ was the most affected parameter by EA, which was followed by TNF- $\alpha$, IL-1 $\beta$ and NF- $\mathrm{BB}$. The maximum inhibitory effect of EA against experimental cytokines occurred at $1000 \mathrm{nM}(\mathrm{p}<0.001)$ (Table 2). 


\subsection{The Effect of PLN and EA on the Expression of NF- $\kappa B$ p65 in REF Cells}

EA also demonstrated highly prominent reductions in the NF- $\mathrm{kB}$ expression in all PLN + EA treated groups as compared to control (Fig. 6).

\subsection{The Effect of PLN and EA on the Expression of p38 in REF Cells}

PLN induced p38 expression remarkably, whereas EA appeared similar to control REF cells. All treated groups containing EA + PLN showed a significant dose-dependent reduction of p38 activity compared to control group (Fig. 7).

\subsection{The Effect of PLN and EA on the Expression of RB in REF Cells}

PLN effectively drove the rate of RB expression higher than the control group in REF cells. Results do not show any obvious alteration in RB expression level by EA versus controls. EA at doses 10, 100 and $1000 \mathrm{nM}$ along with PLN caused a decreasing curve of RB level $(\mathrm{p}<0.001, \mathrm{p}<$ 0.01 and $\mathrm{p}<0.01$, respectively) (Fig. 8).

\subsection{The Effect of PLN and EA on the Expression of p53 in REF Cells}

The changes exhibited by data in the gene expression level, promoted by PLN were significantly different as compared to control group. No prominent change of p53 expression was observed in EA group as compared to control cells. Almost all EA treated groups showed significant reduction as compared to PLN group. The p53 was down-regulated by EA at all the concentrations tested with significant relative fold change. EA at $1000 \mathrm{nM}$ showed the highest significant inhibition of PLN with $\mathrm{p}<0.001$ (Fig. 9). 


\subsection{RT-PCR Analysis of RB and $p 53$}

The examination of data showed that the changes in the expressions of RB and p53 induced by PLN group were significantly higher as compared to control (5.74-fold and 7.27-fold, respectively, $\mathrm{p}<0.001)$. Table 3 expressed no distinct change in the expression levels of RB and p53 by EA treated group as compared to control. Almost all EA co-treated groups displayed a substantial reduction in gene expressions as compared to PLN group. RB has been downregulated in all PLN + EA groups with significant relative fold change in a dose-dependent manner (3.78-fold, 3.30-fold, 2.14-fold and 1.72-fold, respectively). In the case of p53, significant expression changes were observed just in high concentrations of EA (100 and 1000 $\mathrm{nM}$ ) when compared with PLN group $(\mathrm{p}<0.001)$.

\subsection{Western Blot Analysis of NF- $k B, R B, p 38$ and $p 53$}

The analysis of data showed that the fold changes in the gene expressions of NF- $\mathrm{kB}, \mathrm{RB}$ and $\mathrm{p} 53$ induced by PLN group were significantly higher as compared to control. As Fig. 10 shows introducing of EA to REF cells did not exhibit a significant alteration as compared to control group. Nearly, all EA treated groups inhibited the expression of NF-kB, RB and p53 at all concentrations with significant relative fold change $(\mathrm{p}<0.001, \mathrm{p}<0.001$ and $\mathrm{p}<0.001$ respectively). The level of $\mathrm{p} 38$ expression was found to be lower than the others tested, but even though it was significantly intimidated by EA at $1000 \mathrm{nM}$. The $\beta$-actin was used as a positive control.

\subsection{Cell Cycle Analysis}


The cell cycle dissemination of PLN + EA in REF cells was defined in G0/G1, S and G2/M phases. In REF cells, approximately 55\% of control group cells were in G1, 24.58\% in S phase, $6.36 \%$ in G2/M and $13.75 \%$ in sub G1 phase. PLN exhibited G1 arrest, but EA at $1000 \mathrm{mM}$ showed a significant alleviation in sub G1 (fewer apoptotic cells) compared to PLN group. In PLN + EA groups, a significant increase of $\mathrm{S}$ phase distribution was observed, when the concentrations of EA were 10,100 and $1000 \mathrm{nM}(\mathrm{p}<0.01, \mathrm{p}<0.01$ and $\mathrm{p}<0.001)$. EA significantly increased the ratio of cells in S phase compared to PLN group $(\mathrm{p}<0.01$ and $\mathrm{p}<$ 0.001). Indeed, EA made a transition of arrest phase from G1 (in PLN group) to S and G2/M (in PLN + EA at $1000 \mathrm{nM})($ Fig. 11).

\subsection{Telomerase Activity of REF Cells}

EA and control cells groups appeared to be the same without any significant difference. As expected, PLN decreased telomerase activity, while EA promoted this action by almost 2-fold increase at $1000 \mathrm{nM}$ (Fig. 12).

\section{Discussions}

PLN actively committed cellular senescence in REF cells by elevation of oxidative stress factors, expression of aging-related genes, inflammatory cytokines, cell cycle arrest, apoptosis and necrosis and shortening of telomerase. Moreover, EA has the ability to reduce and control all the parameters that had been affected by PLN in REF cells.

Rovillain et al. (2011) showed that more than 1500 genes are up- and down-regulated during senescence in immortalized human fibroblasts. Previously, it was shown that in addition to proper activity of telomerase, activation of the $\mathrm{p} 16-\mathrm{pRB}$ and $\mathrm{p} 53-\mathrm{p} 21$ pathways are crucial for 
cellular senescence. Activation of p53 induces the expression of p21, a CDKN1A suppresses the phosphorylation of $\mathrm{pRB}$ family of proteins, hence activates the $\mathrm{pRB}$ tumor suppressor pathway. On the other hand, p16-pRB pathway is triggered via the activation of $\mathrm{p} 16$, cyclinD/CDK-4,-6 kinases inhibitor that phosphorylates and inactivates the RB protein, and leads to the accumulation of the hypo-phosphorylated active form of RB regulating cell cycle arrest (Kuilman et al., 2010; Xu et al., 2014). Eventually, cells experience telomeric dysfunction, age

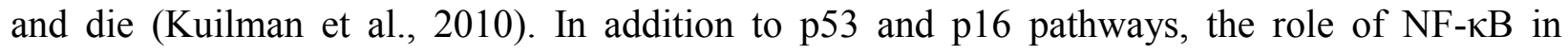
induction and reinforcement of senescence has been proven by its constitutive activation upon aging and its interference with secretion of senescence-associated-secretoryphenotype proteins (SASPP) (Rovillain et al., 2011).

Two intimate characteristics of senescence are found to be oxidative stress and inflammation. Majority of publications revealed that OPs induce oxidative stress via the generation of free radicals/ROS or alteration in their scavenging enzymes. Treatment of cells with oxidative stress leads to DNA single/double-strand breaks, which up-regulates genes and pathways involved in the senescence or cell death, such as p53, p21 and cell cycle arrest (Chen et al., 2005). It has been revealed that ROS acts as both, an upstream signal that triggers p53 activation and a downstream factor that mediates apoptosis (Liu et al., 2008). ROS may interrupt either directly or indirectly on the p53 and p16-RB signal transduction pathways (Iwasa et al., 2003). p38 has also been shown to be activated in senescence, especially in sub-cytotoxic stressful conditions, and controls the activation of $\mathrm{p} 16$ and $\mathrm{p} 53$, as well as the expression of $\mathrm{p} 21$ independent of $\mathrm{p} 53$ (Debacq-Chainiaux et al., 2010; Kuilman et al., 2010). In the absence of severe stresses, p53 even at low level is able to up-regulate several genes with antioxidant products, which are associated with a decrease in intracellular ROS (Sablina et al., 2005). 
Our results are in agreement with literatures, as PLN effectively enhanced LPO and ROS production in REF cells; whereas exposure to EA significantly boosted the FRAP and amount of total thiols in REF cells $(p<0.001)$. Thus, the amount of oxidative stress was found to be significantly lower in REF cells treated with EA. Scientific documentations suggested that combination of antioxidants with OPs leads to the attenuation of the induced damages by these toxicants. Various studies explored how EA markedly depletes ROS generation or abrogates ROS effects on various cells/tissues and in in vivo models (Chen et al., 2007; Bhosle et al., 2005; Pavlica and Gebhardt, 2005).

In addition, to see under which mechanisms senescence was induced in REF cells, the expression of NF-kB, p53, p38 and RB protein was assessed by flow cytometry, western blot and RT-PCR. The expressions of all genes were significantly increased in REF cells exposed to PLN as compared to control, in all 3 assays. No prominent change in gene expression was observed in EA groups as compared to control. All groups containing EA + PLN showed a significant dosedependent reduction of genes activities in comparison to PLN group.

Overall, it is concluded that PLN significantly induced senescence in REF cells through the initiation of oxidative stress and ROS formation, the mediation of $\mathrm{p} 38$ and activation of $\mathrm{p} 53$. Furthermore, over expression of RB was quantified by RT-PCR. This brings another possibility to mind that PLN might introduce senescence to REFs via the activation of RB and perhaps p21. As mentioned, antioxidant can attenuate the effect of p53-induced senescence, thus EA prominently abrogated the PLN oxidant distresses in REF cells.

It is also supposed that inflammatory responses might arise from PLN-induced senescence in REF cells. The progression of acute inflammation might be based on several theories including free radical overproduction, pro-inflammatory enzyme activation and release of pro- 
inflammatory cytokines (El-Shitany et al., 2014). TNF- $\alpha$, IL-1 $\beta$, and IL-6 are known as proinflammatory cytokines/mediators and their expressions are mainly regulated by transcription

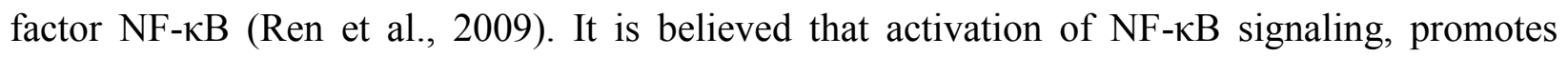
cellular senescence via the up-regulation of various stress associated genes including IL-1 $\beta$, and IL-6. Additionally, NF- $\mathrm{kB}$ is up-regulated in certain chronic diseases associated with age (Laveti et al., 2013, Rovillain et al., 2011). It is well-known that NF-кB activates p53 and this activation is mediated by TNF- $\alpha$. Since, NF- $\mathrm{KB}$ induction occurs as a response to stress/ROS, and p53 arrests cells in G1/S (where DNA repair may be initiated), thus, the activation of p53 by NF- $\mathrm{kB}$ could be a mechanism by which cells can recover from stress (Wu and Lozano, 1994).

REF cells exposed to PLN showed high levels of inflammatory cytokines (TNF- $\alpha$, IL-1 $1 \beta$, IL-6 $\beta$ ) and transcription factor NF- $\mathrm{KB}$ as compared to control cells. The presence of EA in age induced REF cells in a dose-dependent manner lessened the effect of PLN. EA has been proven to possess persuasive anti-inflammatory effects, which confirms our findings. Previous studies revealed that EA is able to reduce inflammation in rat carrageenan-induced paw edema (ElShitany et al., 2014; Mansouri et al., 2015), rat chronic colonic injury (Rosillo et al., 2012), mouse hepatic injury (Gu et al., 2014), and metastasis of breast cancer cells (Rocha et al., 2012) via suppression of pro-inflammatory cytokines TNF- $\alpha$, IL-1 $\beta, N F-\kappa B$ expression and its downstream products. Anti-inflammatory agents, like EA, that suppress NF-kB or its regulated products, might be valuable candidates against aging.

To support our findings, the level of cytochemical $S A-\beta-G A L$ was also measured in REF cells. PLN treated REF cells appeared to have elevated concentration of $S A-\beta-G A L$ as compared to control (indicating senescence); while its activation was alleviated in PLN + EA groups, which shows anti-aging potential effects of EA. 
Later, we decided to get an overview of the viability of the REF cells treated by PLN + EA. ROS and mitochondria play an important role in apoptosis induction. ROS induce p53, which prompts cell cycle arrest (at G1 and/or G2 phase) (Haupt et al., 2003). Kim et al. (2002) suggested that nitric oxide (NO)-activated p38 kinase activates p53 function via transcriptional activation by $\mathrm{NF}-\kappa \mathrm{B}$, and direct phosphorylation of p53 protein leads to apoptosis of articular chondrocytes.

As a result of PLN exposure, the number of apoptotic cells in REF cells was lifted up, which was significantly restored by EA. Interestingly, EA promoted the level of viable cells and reduced apoptosis dose-dependently in PLN induced aging cells. Anti-apoptotic activity of EA and other phenolic acids have been reported in normal blood cells (Khanduja et al., 2006), while some other studies have stated that EA promotes the apoptosis rate in different cancerous cells (Losso et al., 2004; Li et al., 2005). The dual activity of EA to induce apoptosis or not, might be conditional to the cell types and other extra/intracellular stimuli.

Evaluation and control of cellular senescence in G1 cell cycle are major checkpoints in aging research due to the fact that p53-induced G1 arrest in senescent cells, which is clearly pronounced by PLN in this experiment (Chen, 2000; Duan et al., 2005). Regarding flow cytometric analysis, it was predictable that the number of EA treated REF cells in sub G1 (indicating apoptosis cells) was markedly similar to the control group. Besides, apoptotic cells were accumulated in sub G1 in PLN group as compared to those of controls (G1 arrest by PLN). PLN forced REF cells to undergo apoptosis via G1 arrest as a result of p53 activation. EA was found to induce cellular arrest in various stages of cell cycle in different cell lines (Narayanan et al., 1999; Vicinanza et al., 2013).

As an identical symbol of cellular senescence, the level of telomerase activity in REF cells was also assessed. Various studies demonstrated that p53 gene effectively suppresses telomerase 
activity. Our data illustrated that EA is capable enough to modulate inhibited telomerase activity by PLN in REF cells at all the concentration tested. As explained, PLN elevated the expression of p53 gene in REF cells; this led to the down-regulation of this enzyme activity. In contrast, EA had a negligible interference on gene p53 level, which accordingly increased telomerase expression.

Moreover, our study came to two distinct outcomes for the first time. It has been proved that how PLN, an OPs toxicant, induced senescence in REF cells in the deep layers at the cellular and molecular level. Additionally, EA as an antioxidant, exhibited significant protective and inhibitory properties against PLN and rejuvenated the post-oxidant and/or inflammatory damages that persisted in REF cells. Following the exposure of PLN to REF cells, two different oxidative and inflammatory pathways were triggered. PLN stimulated TNF- $\alpha$, and as a result other inflammatory factors, particularly NF- $\mathrm{kB}$ was activated, which initiated the induction of p53 gene. p53 gene mediates the signaling pathways that might lead to either senescence via activation of p53-p21 or recovery of cells from the stress by G1/S arrest. PLN also accelerated the oxidative pathway by positive influences on the up-regulation of $\mathrm{p} 38, \mathrm{p} 53$, and $\mathrm{RB}$ genes. The activation of MINK-p38-PRAK develops phosphorylation of p53 and induces p53-p21 genes. On the other hand, we proved PLN stimulated all corporative parameters that cause senescence in REF cells.

\subsection{Conclusion}

It has been concluded that EA progressively deactivated the PLN-induced senescence in REF cells dose-dependently. Our results re-confirmed the fact that EA exhibits a significant antioxidant role in aging; EA functions might be proportional to the cell types and other cellular 
stimuli. As all the events that happened in REF cells were initiated by oxidative stress/ROS generation, EA preceded a dominant action to revoke ROS by manipulating oxidative/inflammatory biomarkers within the cells. Our study provides a molecular explanation of PLN in senescent state, as well as new insight into the action of EA as a potent senescence inhibitor. Overall, this is the first report regarding the assessment of senescence-associated tumor suppressor networks and induction of $S A-\beta-G A L$ activity, oxidative stress parameters, inflammatory cytokines, cell cycle/viability and the expression of telomerase activity in PLNinduced senescence in REF cells as well as the protective role of EA.

\section{Conflict of interest}

The authors declare no conflict of interest.

\section{Authors contribution}

All authors contributed according to ICMJE guideline.

\section{Acknowledgments}

This study was in part supported by an independent grant of the corresponding author from Tehran University of Medical Sciences (ID: 94-04-45-31137) and Iran National Science Foundation (INSF).

\section{References}

Abdollahi, M., Larijani, B., Rahimi, R., Salari, P., 2005. Role of oxidative stress in osteoporosis. Future Med. 2 (5), 787-796.

Armstrong, D., Browne, R., 1994. The analysis of free radicals, lipid peroxides, antioxidant enzymes and compounds related to oxidative stress as applied to the clinical chemistry laboratory. Adv. Exp. Med. Biol. 366: 43-58.

Altuntas, I., Delibas, N., Doguc, D.K., Ozmen, S., Gultekin, F., 2003. Role of reactive oxygen species in organophosphate insecticide phosalone toxicity in erythrocytes in vitro. Toxicol. In Vitro. 17 (2), 153-157. 
Bahadar, H., Abdollahi, M., Maqbool, F., Baeeri, M., Niaz, K., 2014. Mechanistic Overview of Immune Modulatory Effects of Environmental Toxicants. Inflamm. Allergy Drug Targets. 13, 382-386.

Bahadar, H., Maqbool, F., Mostafalou, S., Baeeri, M., Rahimifard, M., Navaei-Nigjeh, M., Abdollahi, M., 2015. Assessment of benzene induced oxidative impairment in rat isolated pancreatic islets and effect on insulin secretion. Environ. Toxicol. Pharmacol. 39, 1161-1169.

Benzie, I.F., Strain, J.J., 1996. The ferric reducing ability of plasma (FRAP) as a measure of antioxidant power: the FRAP assay. Anal. Biochem. 239(1): 70-76.

Bhosle, S.M., Huilgol, N.G., Mishra, K.P., 2005. Enhancement of radiation-induced oxidative stress and cytotoxicity in tumor cells by ellagic acid. Clin. Chim. Acta. 359, 89-100.

Bisen, P.S., Bundela, S.S., Sharma, A., 2012. Ellagic Acid Chemopreventive Role in Oral Cancer. J. Cancer Sci. Ther. 4 (2), 23-30.

Campisi, J., 2001. Cellular senescence as a tumor-suppressor mechanism. Trends in cell biology, $11, \mathrm{~S} 27-\mathrm{S} 31$.

Chen, J.H., Hales, C.N., Ozanne, S.E., 2007. DNA damage, cellular senescence and organismal ageing: causal or correlative? Nucleic Acids Res. 35, 7417-7428.

Chen, J.H., Ozanne, S.E., Hales, C.N., 2005. Heterogeneity in premature senescence by oxidative stress correlates with differential DNA damage during the cell cycle. DNA Repair. 4, 1140-1148.

Chen, Q.M., 2000. Replicative Senescence and Oxidant-Induced Premature Senescence: Beyond the Control of Cell Cycle Checkpoints. Ann. N. Y. Acad. Sci. 908, 111-125.

Debacq-Chainiaux, F., Boilan, E., Le Moutier, J.D., Weemaels, G., Toussaint, O., 2010. p38MAPK in the Senescence of Human and Murine Fibroblasts. Protein Meta. Homeo. Aging. 694, 126-137.

Di Fagagna, F.D.A., Reaper, P.M., Clay-Farrace, L., Fiegler, H., Carr, P., Von Zglinicki, T., Saretzki, G., Carter, N.P., Jackson, S.P., 2003. A DNA damage checkpoint response in telomere-initiated senescence. Nature, 426, 194-198.

Duan, J., Duan, J., Zhang, Z., Tong, T., 2005. Irreversible cellular senescence induced by prolonged exposure to $\mathrm{H} 2 \mathrm{O} 2$ involves DNA-damage-and-repair genes and telomere shortening. Int. J. Biochem. Cell Biol. 37, 1407-1420.

El-Shitany, N.A., El-Bastawissy, E.A., El-Desoky, K., 2014. Ellagic acid protects against carrageenan-induced acute inflammation through inhibition of nuclear factor kappa B, inducible cyclooxygenase and proinflammatory cytokines and enhancement of interleukin-10 via an antioxidant mechanism. Int. Immunopharmacol. 19, 290-299.

Esmaily, H., Vaziri-Bami, A., Miroliaee, A.E., Baeeri, M., Abdollahi, M., 2011. The correlation between NF- $\mathrm{kB}$ inhibition and disease activity by coadministration of silibinin and ursodeoxycholic acid in experimental colitis. Fundam. Clin. Pharmacol. 25(6):723-33.

Fitzgerald, A., Osman, A., Xie, T., Patel, A., Skinner, H., Sandulache, V., Myers, J., 2015. Reactive oxygen species and p21Waf1/Cip1 are both essential for p53-mediated senescence of head and neck cancer cells. Cell Death Dis. 6, 1678-1688.

Fulton, M.H., Key, P.B., 2001. Acetylcholinesterase inhibition in estuarine fish and invertebrates as an indicator of organophosphorus insecticide exposure and effects. Environ Toxicol Chem. 20 (1), 37-45. 
Ghasemi-Niri, S.F., Maqbool, F., Baeeri, M., Gholami, M., Abdollahi, M., 2016. Phosaloneinduced inflammation and oxidative stress in the colon: Evaluation and treatment. World J. Gastroenterol. 22, 4999-5011.

Gu, L., Deng, W.S., Liu, Y., Jiang, C.H., Sun, L.C., Sun, X.F., Xu, Q., Zhou, H., 2014. Ellagic acid protects Lipopolysaccharide/d-galactosamine-induced acute hepatic injury in mice. Int. Immunopharmacol. 22, 341-345.

Han, D.H., Lee, M.J., Kim, J.H., 2006. Antioxidant and apoptosis-inducing activities of ellagic acid. Anticancer Res. 26(5A), 3601-3606.

Han, J., Sun, P., 2007. The pathways to tumor suppression via route p38. Trends Biochem. Sci. 32, 364-371.

Haupt, S., Berger, M., Goldberg, Z., Haupt, Y., 2003. Apoptosis-the p53 network. J. Cell Sci. 116, 4077-4085.

Hodjat, M., Rezvanfar, M.A., Abdollahi, M., 2015. A systematic review on the role of environmental toxicants in stem cells aging. Food Chem. Toxicol. 86, 298-308.

HU, M.L., 1994. Measurement of protein thiol groups and glutathione in plasma. Methods Enzymol. 233: 380-385.

Iwasa, H., Han, J., Ishikawa, F., 2003. Mitogen-activated protein kinase p38 defines the common senescence-signalling pathway. Genes Cells. 8, 131-144.

Kajbaf, F., Mojtahedzadeh, M., Abdollahi, M., 2007. Mechanisms underlying stress-induced hyperglycemia in critically ill patients. Future Med. 4 (1), 97-106.

Khanduja, K.L., Avti, P.K., Kumar, S., Mittal, N., Sohi, K.K., Pathak, C.M., 2006. Antiapoptotic activity of caffeic acid, ellagic acid and ferulic acid in normal human peripheral blood mononuclear cells: a Bcl-2 independent mechanism. Biochim. Biophys. Acta, 1760, 283-289.

Kim, S.J., Hwang, S.G., Shin, D.Y., Kang, S.S., Chun, J.S., 2002. p38 Kinase Regulates Nitric Oxide-induced Apoptosis of Articular Chondrocytes by Accumulating p53 via NF Bdependent Transcription and Stabilization by Serine 15 Phosphorylation. J. Biol. Chem. 277, 33501-33508.

Kregel, K.C., Zhang, H.J., 2007. An integrated view of oxidative stress in aging: basic mechanisms, functional effects, and pathological considerations. Am. J. Physiol. Regul. Integr. Comp. Physiol. 292, 18-36.

Kuilman, T., Michaloglou, C., Mooi, W.J., Peeper, D.S., 2010. The essence of senescence. Genes Dev. 24, 2463-2479.

Laveti, D., Kumar, M., Hemalatha, R., Sistla, R., Gm Naidu, V., Talla, V., Verma, V., Kaur, N., Nagpal, R., 2013. Anti-inflammatory treatments for chronic diseases: a review. Inflamm. Allergy Drug Targets. 12, 349-361.

Lee, A.C., Fenster, B.E., Ito, H., Takeda, K., Bae, N.S., Hirai, T., Yu, Z.X., Ferrans, V.J., Howard, B.H., Finkel, T., 1999. Ras proteins induce senescence by altering the intracellular levels of reactive oxygen species. J. Biol. Chem. 274, 7936-7940.

Li, H.L., Chen, D.D., Li, X.H., Zhang, H.W., Lu, Y., Ye, C.L., Ren, X.D., 2002. Changes of NF$\mathrm{kB}, \mathrm{p} 53, \mathrm{Bcl}-2$ and caspase in apoptosis induced by JTE-522 in human gastric adenocarcinoma cell line AGS cells: role of reactive oxygen species. World J. Gastroenterol. 8, 431-435.

Li, T.M., Chen, G.W., Su, C.C., Lin, J.G., Yeh, C.C., Cheng, K.C., Chung, J.G., 2005. Ellagic acid induced p53/p21 expression, G1 arrest and apoptosis in human bladder cancer T24 cells. Anticancer Res. 25, 971-979. 
Liu, B., Chen, Y., Clair, D. K. S., 2008. ROS and p53: a versatile partnership. Free Radi. Biol. Med. 44, 1529-1535.

Losso, J.N., Bansode, R.R., Trappey, A., Bawadi, H.A. Truax, R., 2004. In vitro antiproliferative activities of ellagic acid. J. Nutr. Biochem. 15, 672-678.

Manayi, A., Saeidnia, S., Gohari, A.R., Abdollahi, M., 2014. Methods for the discovery of new anti-aging products-targeted approaches. Expert Opin. Drug Discov. 9, 383-405.

Mansouri, M.T., Hemmati, A.A., Naghizadeh, B., Mard, S.A., Rezaie, A., Ghorbanzadeh, B., 2015. A study of the mechanisms underlying the anti-inflammatory effect of ellagic acid in carrageenan-induced paw edema in rats. Ind. J. Pharmacol. 47 (3), 292-298.

Maqbool, F., Mostafalou, S., Bahadar, H., Abdollahi, M., 2015. Review of endocrine disorders associated with environmental toxicants and possible involved mechanisms. Life Sci. $145,265-273$.

Momtaz S, Hussein AA, Ostad SN, Abdollahi M, Lall N. Growth inhibition and induction of apoptosis in human cancerous HeLa cells by Maytenus procumbens. Food Chem. Toxicol. 2013; 51:38-45.

Moeinian, M., Ghasemi-Niri, S.F., Mozaffari, S., Abdolghaffari, A.H., Baeeri, M., NavaeaNigjeh, M., Abdollahi, M., 2014. Beneficial effect of butyrate, Lactobacillus casei and Lcarnitine combination in preference to each in experimental colitis. World $\mathrm{J}$. Gastroenterol. 20, 10876.

Morris, S.C., Lee, T.H., 1984. The toxicity and teratogenicity of Solanaceae glycoalkaloids, particularly those of the potato (Solanum tuberosum): a review. Food Technol Aust. 36, 118-124.

Mostafalou, S., Abdollahi, M., 2013. Pesticides and human chronic diseases: evidences, mechanisms, and perspectives. Toxicol. Appl. Pharmacol. 268, 157-177.

Mostafalou, S. Abdollahi, M., 2016. Pesticides: an update of human exposure and toxicity. Arch Toxicol. doi:10.1007/s00204-016-1849-x

Muñoz-Muñoz JL, Garcia-Molina F, Garcia-Molina M, Tudela J, García-Cánovas F, RodriguezLopez JN., 2009. Ellagic acid: characterization as substrate of polyphenol oxidase. IUBMB Life. 61 (2), 171-177.

Najafi, A., Mojtahedzadeh, M., Mahmoodpoor, A., Aghamohammadi, M., Ahmadi, A., Nahreini, S., Pazuki, M., Khajavi, M.R., Abdollahi, M., 2009. Effect of N-acetylcysteine on microalbuminuria in patients with acute respiratory distress syndrome. Arch. Med. Sci. 5, 408-14.

Narayanan, B.A., Geoffroy, O., Willingham, M.C., Re, G.G., Nixon, D.W., 1999. p53/p21 (WAF1/CIP1) expression and its possible role in G1 arrest and apoptosis in ellagic acid treated cancer cells. Cancer Lett. 136, 215-221.

Narita, M., Nuñez, S., Heard, E., Narita, M., Lin, A.W., Hearn, S.A., Spector, D.L., Hannon, G. J., Lowe, S.W., 2003. Rb-mediated heterochromatin formation and silencing of E2F target genes during cellular senescence. Cell. 113, 703-716.

Pasquet, J., Mazuret, A., Fournel, J., Koenig, F.H., 1976. Acute oral and percutaneous toxicity of phosalone in the rat, in comparison with azinphosmethyl and parathion. Toxicol Appl Pharmacol. 37(1), 85-92.

Passos, J.F., Nelson, G., Wang, C., Richter, T., Simillion, C., Proctor, C.J., Miwa, S., Olijslagers, S., Hallinan, J., Wipat, A., 2010. Feedback between p21 and reactive oxygen production is necessary for cell senescence. Mol. Syst. Biol. 6, 1-14. 
Pavlica, S., Gebhardt, R., 2005. Protective effects of ellagic and chlorogenic acids against oxidative stress in PC12 cells. Free Radi. Res. 39, 1377-1390.

Rahimifard, M., Navaei-Nigjeh, M., Baeeri, M., Maqbool, F., Abdollahi, M., 2015. Multiple protective mechanisms of alpha-lipoic acid in oxidation, apoptosis and inflammation against hydrogen peroxide induced toxicity in human lymphocytes. Mol. Cell. Biochem. 403, 179-186.

Ren, J.L., Pan, J.S., Lu, Y.P., Sun, P., Han, J., 2009. Inflammatory signaling and cellular senescence. Cell. Signal. 21, 378-383.

Rezvanfar, M.A., Hodjat, M., Abdollahi, M., 2016. Growing knowledge of using embryonic stem cells as a novel tool in developmental risk assessment of environmental toxicants. Life Sci. In Press.

Rocha, A., Wang, L., Penichet, M., Martins-Green, M., 2012. Pomegranate juice and specific components inhibit cell and molecular processes critical for metastasis of breast cancer. Breast Cancer Res. Treat. 136, 647-658.

Rosillo, M.A., Sánchez-Hidalgo, M., Cárdeno, A., Aparicio-Soto, M., Sánchez-Fidalgo, S., Villegas, I., De La Lastra, C.A., 2012. Dietary supplementation of an ellagic acidenriched pomegranate extract attenuates chronic colonic inflammation in rats. Pharmacol. Res. 66, 235-242.

Rovillain, E., Mansfield, L., Caetano, C., Alvarez-Fernandez, M., Caballero, O.L., Medema, R. H., Hummerich, H., Jat, P.S., 2011. Activation of nuclear factor-kappa B signalling promotes cellular senescence. Oncogene. 30, 2356-2366.

Sablina, A.A., Budanov, A.V., Ilyinskaya, G.V., Agapova, L.S., Kravchenko, J.E., Chumakov, P.M., 2005. The antioxidant function of the p53 tumor suppressor. Nat. Med. 11, 13061313.

Saeidnia, S., Abdollahi, M., 2013a. Antioxidants: Friends or foe in prevention or treatment of cancer: The debate of the century. Toxicol. Appl. Pharmacol. 271, 49-63.

Saeidnia, S., Abdollahi, M., 2013b. Toxicological and pharmacological concerns on oxidative stress and related diseases. Toxicol. Appl. Pharmacol. 273, 442-455.

Sanadgol, N., Mostafaie, A., Mansouri, K., Bahrami, G., 2012. Effect of palmitic acid and linoleic acid on expression of ICAM-1 and VCAM-1 in human bone marrow endothelial cells (HBMECs). Arch. Med. Sci. 8, 192-198.

Schmittgen, TD., Livak, KJ., 2008. Analyzing real-time PCR data by the comparative C(T) method. Nat Protoc. 3, 1101-1108.

Seeram, N.P., Lee, R., Heber, D., 2004. Bioavailability of ellagic acid in human plasma after consumption of ellagitannins from pomegranate (Punica granatum L.) juice. Clin Chim Acta. 348, 63-68.

Serrano, M., Lin, A.W., Mccurrach, M.E., Beach, D., Lowe, S.W., 1997. Oncogenic ras provokes premature cell senescence associated with accumulation of p53 and p16 INK4a. Cell. 88, 593-602.

Soltaninejad, K., Abdollahi, M., 2009. Current opinion on the science of organophosphate pesticides and toxic stress: a systematic review. Med. Sci. Monit. Basic Res. 15, 75-90.

US EPA., 2001. Report of FQPA tolerance reassessment progress and interim risk management decision for phosalone. OPPT (7608C). EPA 738-R-01-001.

Vattem, D., Shetty, K., 2005. Biological functionality of ellagic acid: a review. J. Food Biochem. 29, 234-266. 
Vicinanza, R., Zhang, Y., Henning, S.M., Heber, D., 2013. Pomegranate juice metabolites, ellagic acid and urolithin a, synergistically inhibit androgen-independent prostate cancer cell growth via distinct effects on cell cycle control and apoptosis. Evid. Based Complment. Alternat. Med. Article ID: 247504, 1-12.

Von Zglinicki, T., 2002. Oxidative stress shortens telomeres. Trends Biochem. Sci. 27, 339-344.

W.H.O. 2006. The impact of pesticides on health: Preventing intentional and unintentional deaths from pesticide poisoning. Geneva: WHO. http://www.who.int/mental health/prevention/suicide/en/ PesticidesHealth2.pdf

Weisburg, J.H., Schuck, A.G., Reīss, S.E., Wolf, B.J., Fertel, S.R., Zuckerbraun, H.L., Babich, H., 2013. Ellagic acid, a dietary polyphenol, selectively cytotoxic to HSC-2 oral carcinoma cells. Anticancer Res. 33, 1829-1836.

Wu, H., Lozano, G., 1994. NF-kappa B activation of p53. A potential mechanism for suppressing cell growth in response to stress. J. Biol. Chem. 269, 20067-20074.

Xu, Y., Li, N., Xiang, R., Sun, P., 2014. Emerging roles of the p38 MAPK and $\mathrm{PI} 3 \mathrm{~K} / \mathrm{AKT} / \mathrm{mTOR}$ pathways in oncogene-induced senescence. Trends Biochem. Sci. 39, 268-276.

Yusuf, B., Gopurappilly, R., Dadheech, N., Gupta, S., Bhonde, R., Pal, R., 2013. Embryonic fibroblasts represent a connecting link between mesenchymal and embryonic stem cells. Dev. Growth Differ. 55, 330-340.

Zhang, H.M., Zhao, L., Li, H., Xu, H., Chen, W.W., Tao, L., 2014. Research progress on the anticarcinogenic actions and mechanisms of ellagic acid. Cancer Biol. Med. 11 (2), 92100. 


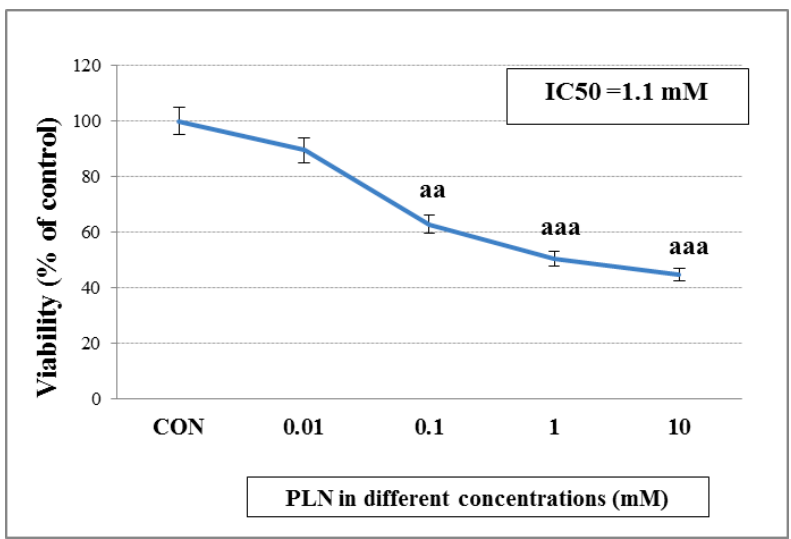

Fig. 1. Effect of various concentrations of PLN on viability in REF cells. Results are expressed as mean \pm SEM. ${ }^{\text {aaa }}$ : significant difference from control group at $\mathrm{p}<0.001,{ }^{\text {aa }}$ : significant difference from control group at $\mathrm{p}<0.01$

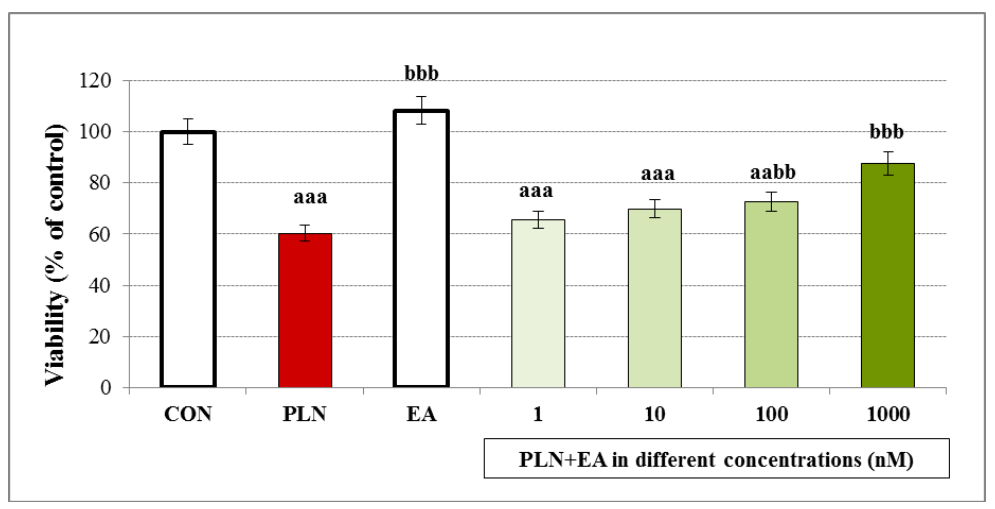


Fig. 2. Effect of PLN (1/10 IC50) and various concentrations of EA on mitochondrial activity in REF cells. Results are expressed as mean \pm SEM. ${ }^{\text {aaa }}$ : significant difference from control group at $\mathrm{p}<0.001,{ }^{\text {aa }}$ : significant difference from control group at $\mathrm{p}<0.01,{ }^{\text {bbb }}$ : significant difference from PLN group at $\mathrm{p}<0.001,{ }^{\text {bb }}$ : significant difference from PLN group at $\mathrm{p}<0.01$. 

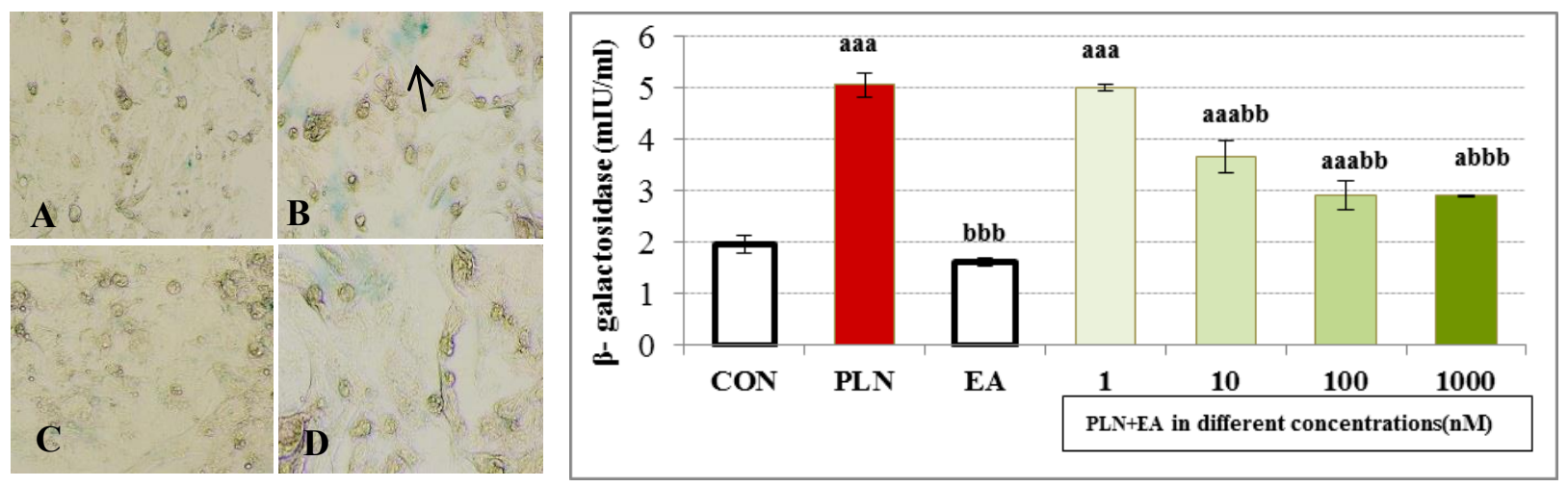

Fig. 3. Effect of various concentrations of PLN and EA on $\beta$-galactosidase activity of the REF cells at $\mathrm{pH}$ 6. Arrow indicates senescent cell. A: Control group, B: PLN group, C: EA group and D: PLN+EA group. Results are expressed as mean \pm SEM. ${ }^{\text {aaa }}$ : significant difference from control group at $\mathrm{p}<0.001$. $^{\mathrm{a}}$ : significant difference from control group at $\mathrm{p}<0.05$. $^{\text {bbb }}$ : significant difference from PLN group at $\mathrm{p}<0.001,{ }^{\mathrm{bb}}$ : significant difference from PLN group at $\mathrm{p}<0.01$. 


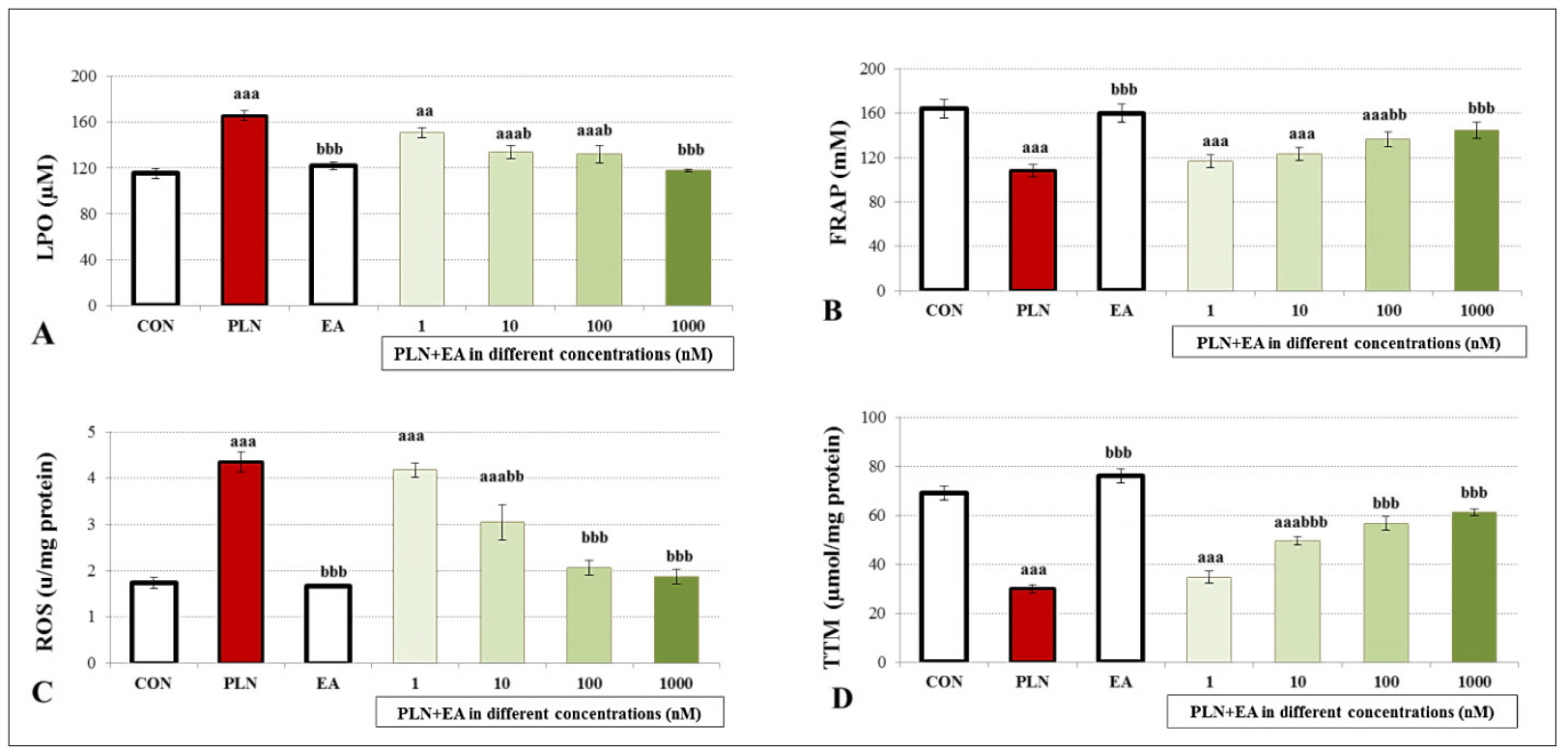

Fig. 4. Effect of PLN and various concentrations of EA on oxidative stress biomarkers in REF cells. A: LPO (lipid peroxidation), B: FRAP (ferric reducing antioxidant power), C: ROS (reactive oxygen species) and D: TTM (total thiol molecules) assay. Results are expressed as mean \pm SEM. ${ }^{\text {aaa }}$ : significant difference from control group at $\mathrm{p}<0.001$, aa: significant difference from control group at $\mathrm{p}<0.01,{ }^{\text {bbb }}$ : significant difference from PLN group at $\mathrm{p}<0.001,{ }^{\mathrm{bb}}$ : significant difference from PLN group at $\mathrm{p}<0.01$. 

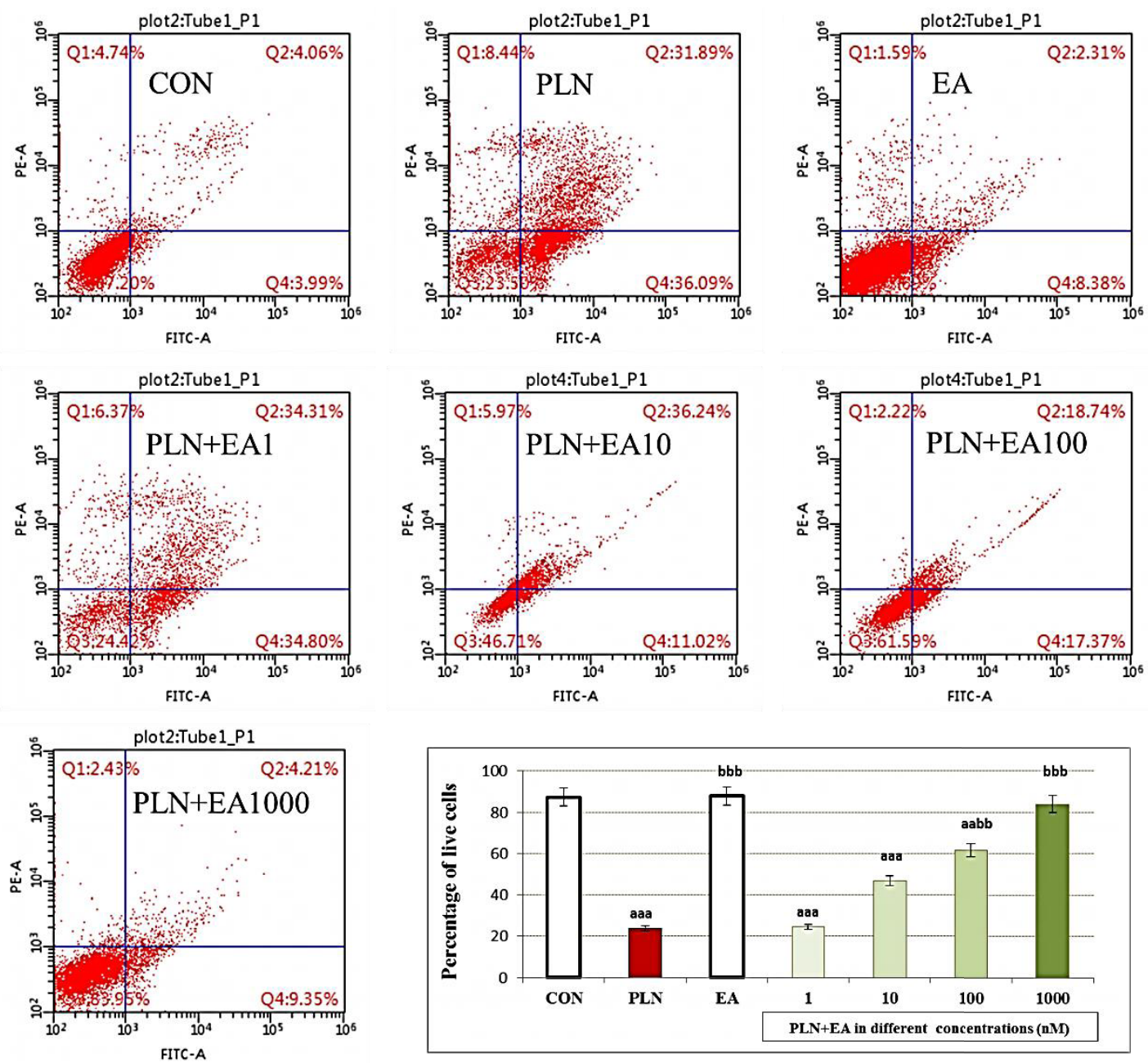

Fig. 5. Flow cytometry assessment of PLN and different concentrations of EA on REFs. Changes in percent of live, apoptotic and necrotic populations of the REF cells are exhibited. Furthermore, variations in the percent of live cells are shown in the graph. Left lower square shows live cells with FITC $^{-}$and $\mathrm{PI}^{-}$, right lower square indicates early apoptotic cells with FITC $^{+}$ and $\mathrm{PI}^{-}$, right upper square displays late apoptotic cells with $\mathrm{FITC}^{+}$and $\mathrm{PI}^{+}$and left upper square expresses necrotic cells with FITC $^{-}$and $\mathrm{PI}^{+}$. Results are expressed as mean \pm SEM. ${ }^{\text {aaa: }}$ significant difference from control group at $\mathrm{p}<0.001,{ }^{\text {aa }}$ : significant difference from control group at $\mathrm{p}<0.01,{ }^{\mathrm{bbb}}$ : significant difference from PLN group at $\mathrm{p}<0.001,{ }^{\mathrm{bb}}$ : significant difference from PLN group at $\mathrm{p}<0.01$. 

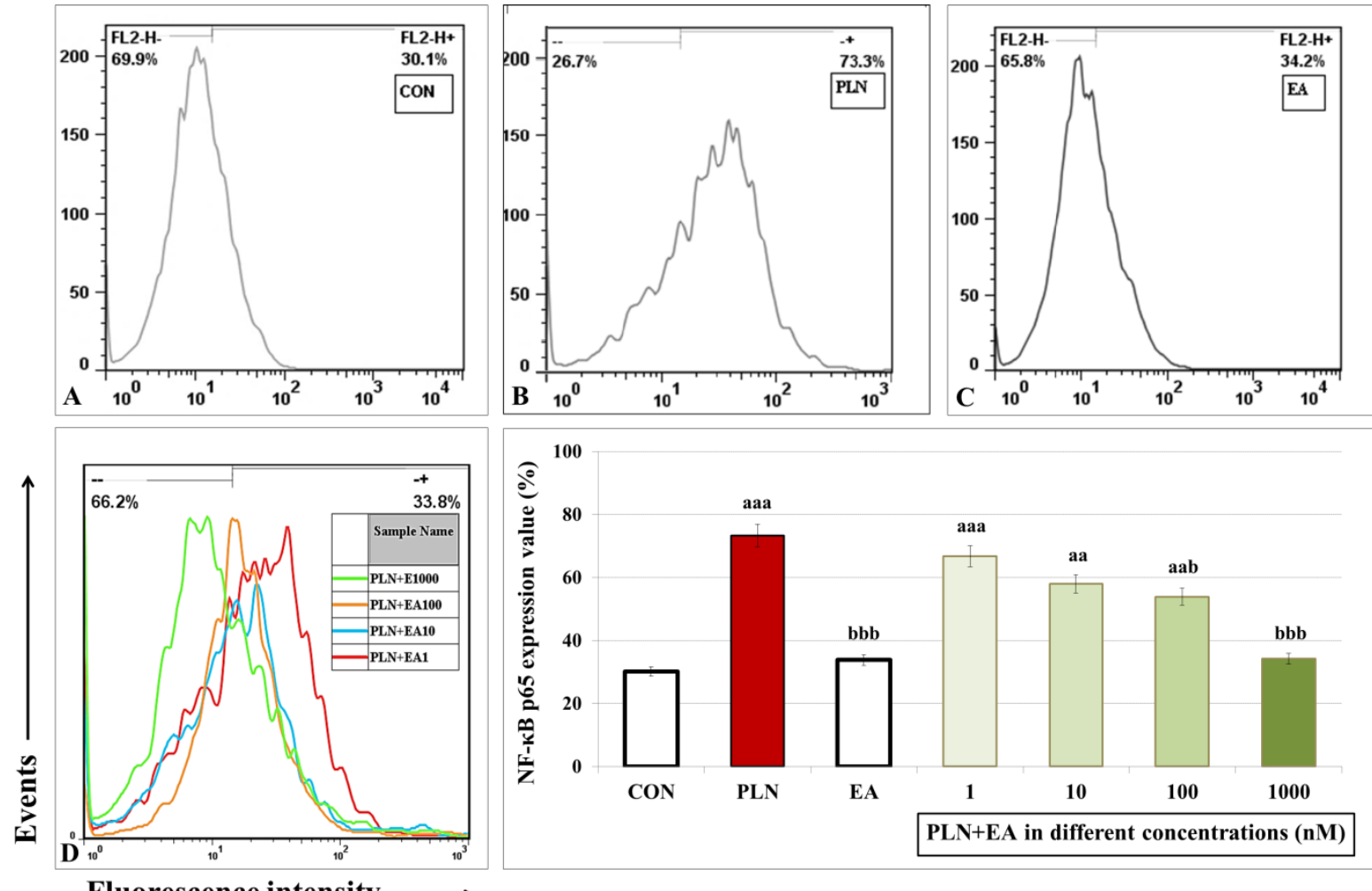

Fluorescence intensity

Fig. 6. Effect of PLN and various concentrations of EA on expression of NF-kB p65 in REFs by flow cytometry. Results are expressed as mean \pm SEM. A: CON group, B: PLN group, C: EA group and D: PLN+EA in different concentrations. ${ }^{\text {aaa. }}$ : significant difference from control group at $\mathrm{p}<0.001,{ }^{\mathrm{a} a}$ : significant difference from control group at $\mathrm{p}<0.01,{ }^{\mathrm{bbb}}$ : significant difference from PLN group at $\mathrm{p}<0.001,{ }^{\mathrm{b}}$ : significant difference from PLN group at $\mathrm{p}<0.05$. 

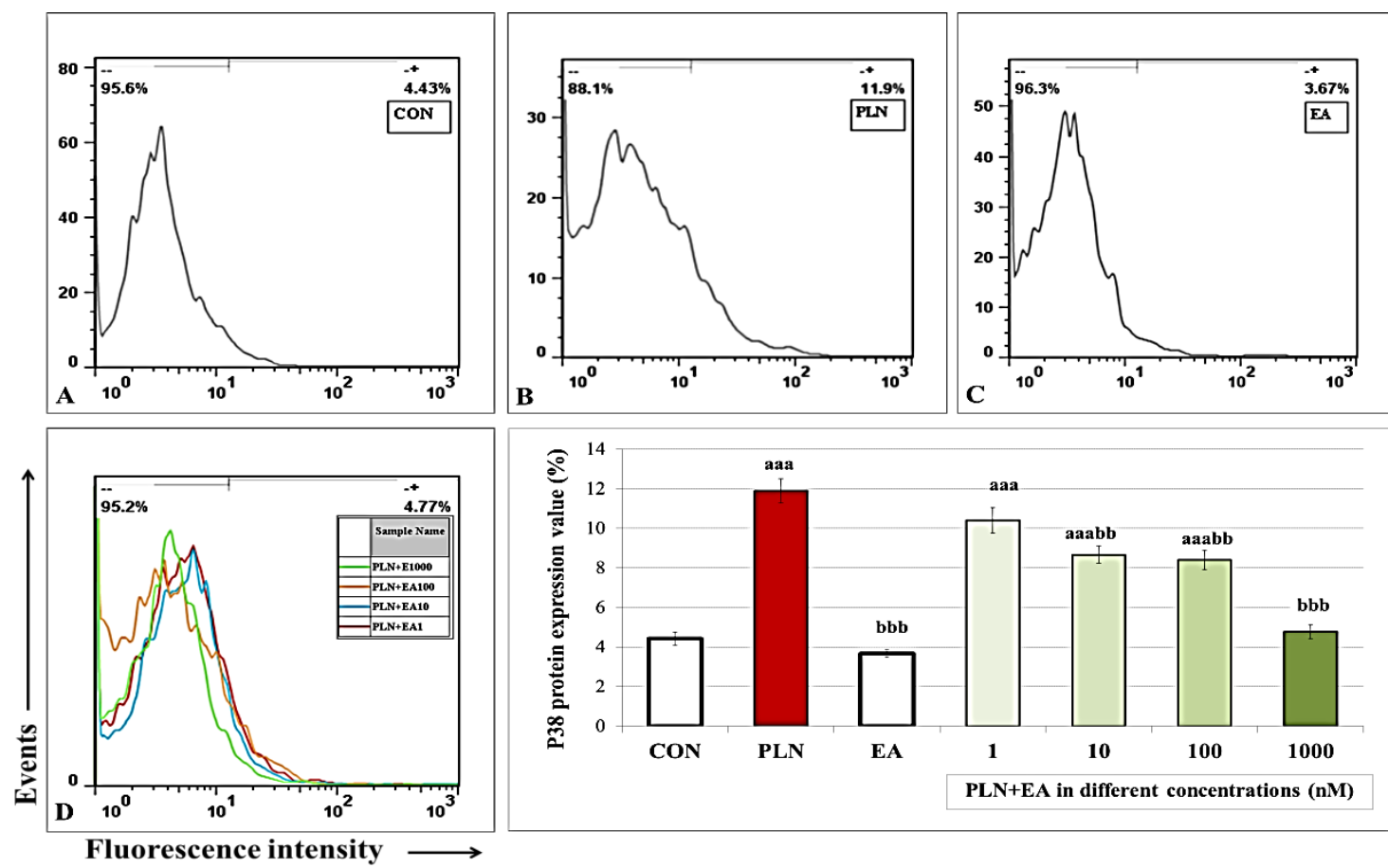

Fig. 7. Effect of PLN and various concentrations of EA on expression of p38 in REFs by flow cytometry. Results are expressed as mean \pm SEM. A: CON group, B: PLN group, C: EA group and D: PLN+EA in different concentrations. ${ }^{\text {aaa }}$ : significant difference from control group at $\mathrm{p}<$ $0.001,{ }^{b b b}$ : significant difference from PLN group at $\mathrm{p}<0.001,{ }^{\text {bb }}$ : significant difference from PLN group at $\mathrm{p}<0.01$. 

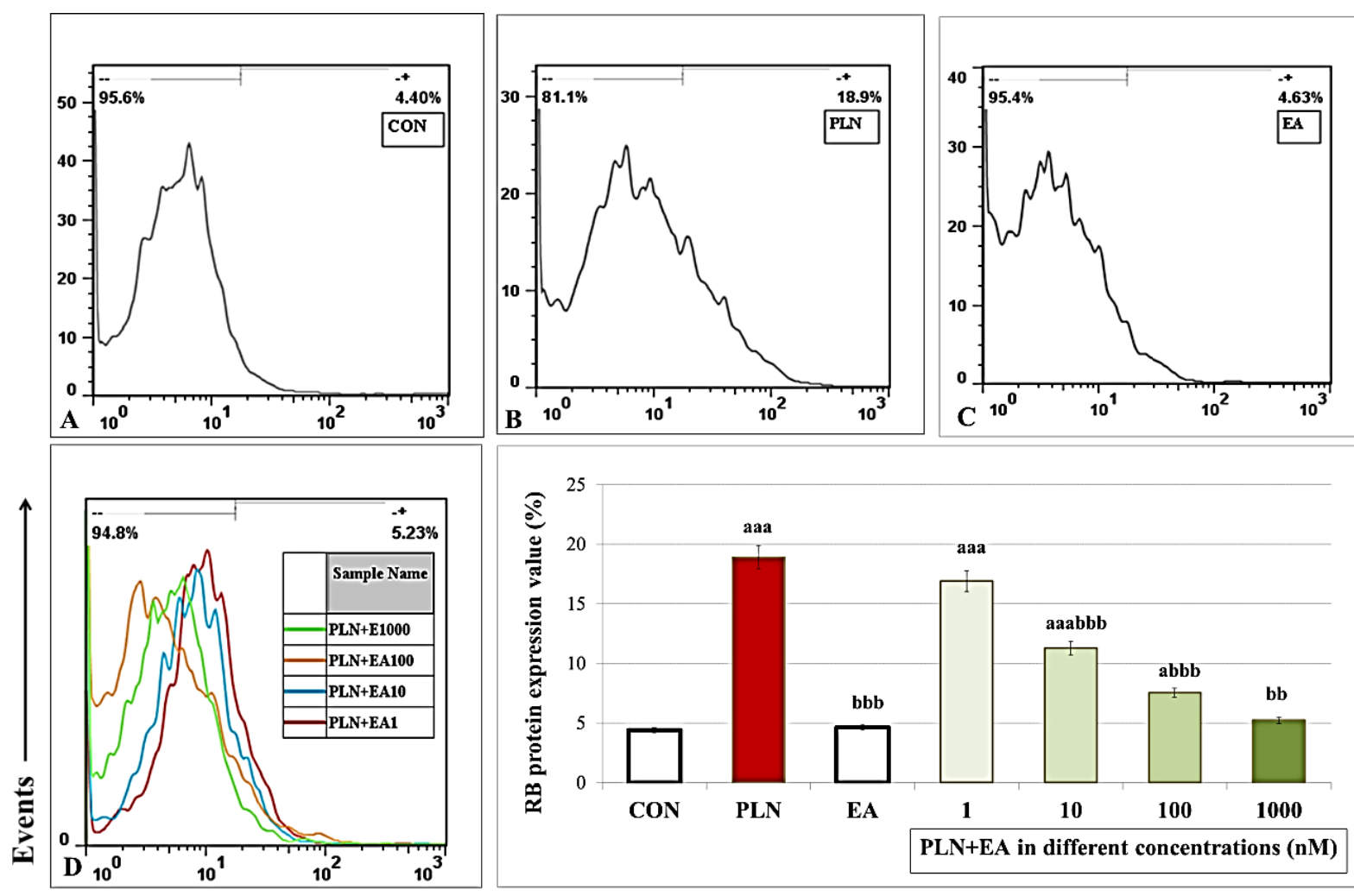

Fluorescence intensity $\longrightarrow$

Fig. 8. Effect of PLN and various concentrations of EA on expression of RB in REFs by flow cytometry. Results are expressed as mean \pm SEM. A: CON group, B: PLN group, C: EA group and D: PLN+EA in different concentrations. ${ }^{\text {aaa }}$ : significant difference from control group at $\mathrm{p}<$ 0.001 , a : significant difference from control group at $\mathrm{p}<0.05,{ }^{\mathrm{bbb}}$ : significant difference from PLN group at $\mathrm{p}<0.001,{ }^{\mathrm{bb}}$ : significant difference from PLN group at $\mathrm{p}<0.01$. 

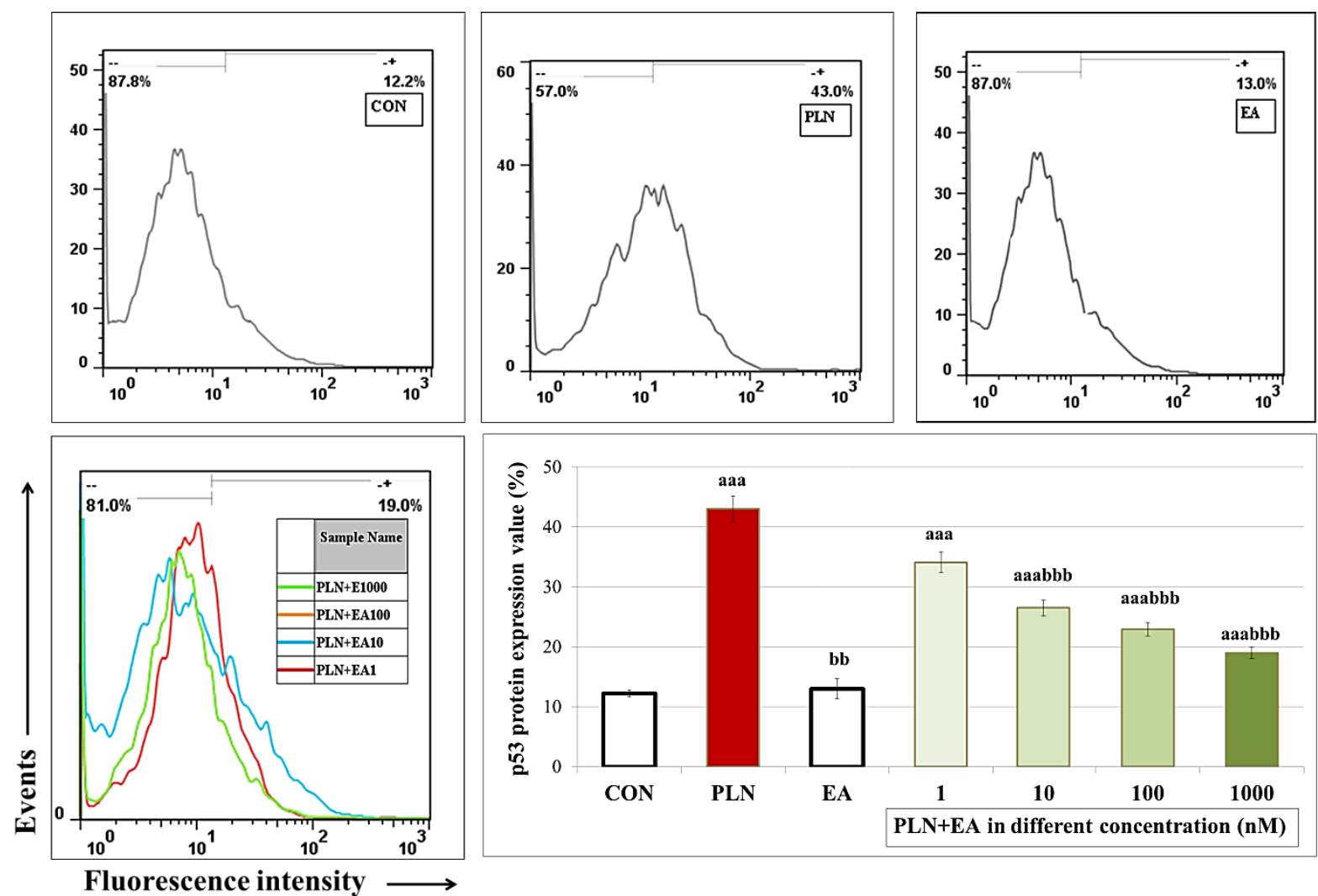

Fig. 9. Effect of PLN and various concentrations of EA on expression of p53 in REFs by flow cytometry. Results are expressed as mean \pm SEM. ${ }^{\text {aaa }}$ : significant difference from control group at $\mathrm{p}<0.001,{ }^{\mathrm{bbb}}$ : significant difference from PLN group at $\mathrm{p}<0.001,{ }^{\mathrm{bb}}$ : significant difference from PLN group at $\mathrm{p}<0.01$. 

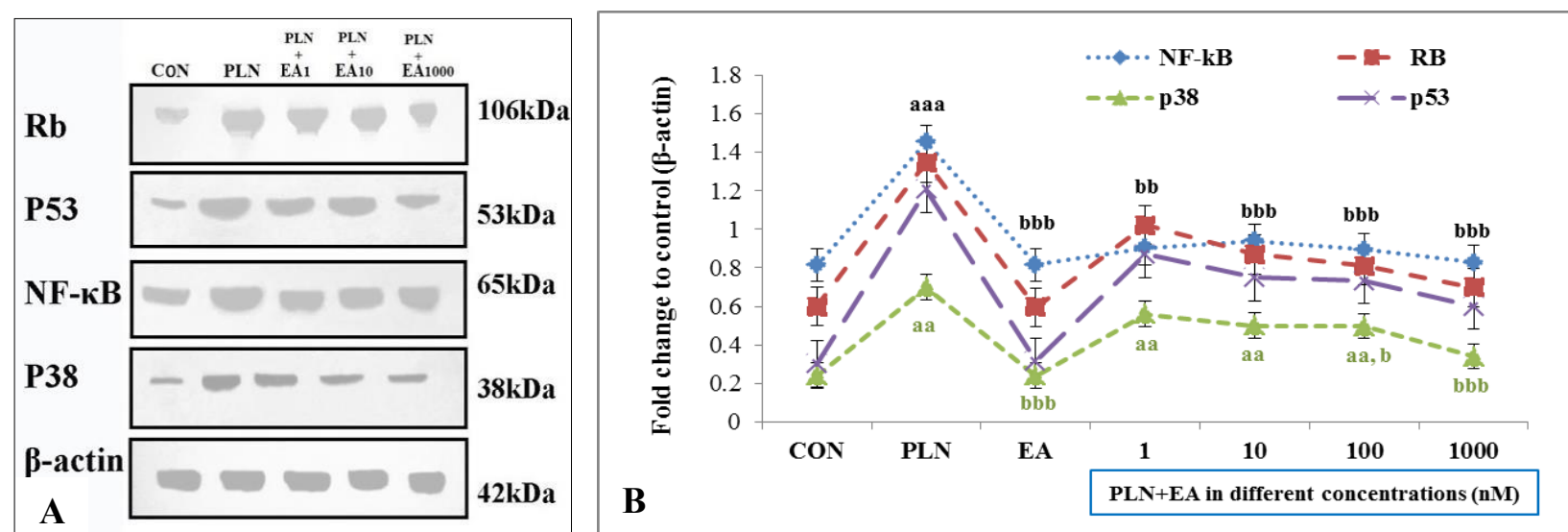

Fig. 10. Effect of PLN and various concentrations of EA on expression of p38, NF-kB, p53 and $\mathrm{RB}$ proteins by western blot. Results are expressed as mean \pm SEM. A: qualitative and B: quantitative western blotting. ${ }^{\text {aaa. }}$ : significant difference from control group at $\mathrm{p}<0.001$, ${ }^{\text {aa }}$ : significant difference from control group at $\mathrm{p}<0.01,{ }^{\mathrm{bbb}}$ : significant difference from PLN group at $\mathrm{p}<0.001,{ }^{\mathrm{b}}$ : significant difference from PLN group at $\mathrm{p}<0.01,{ }^{\mathrm{b}}$ : significant difference from PLN group at $\mathrm{p}<0.05$. 


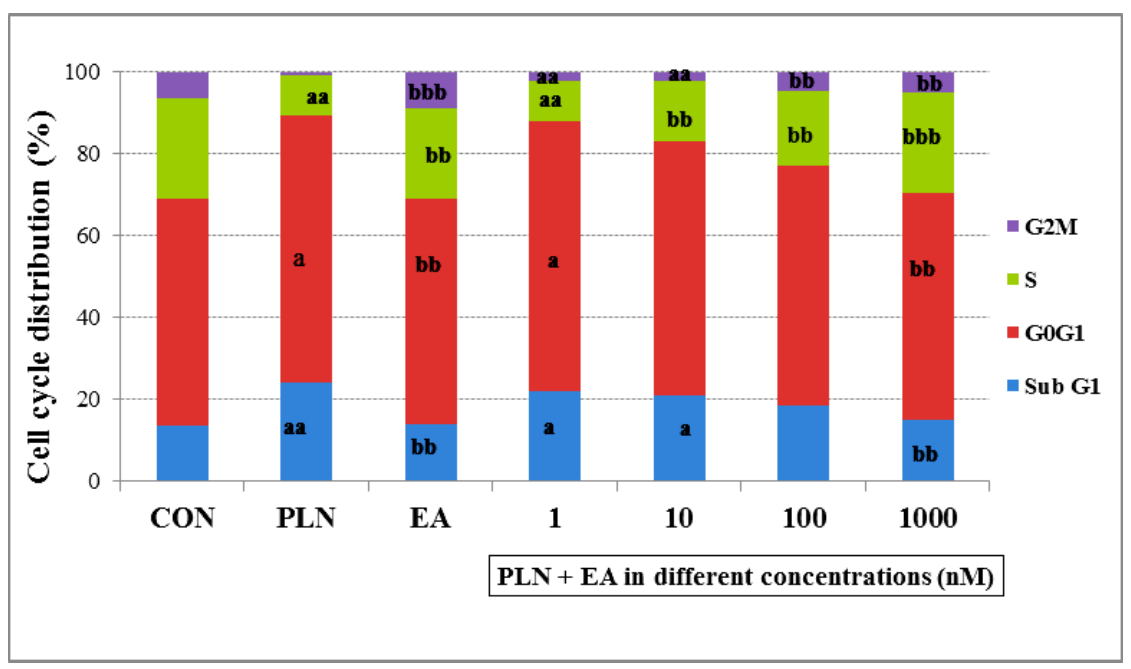

Fig. 11. Effect of PLN and various concentrations of EA on cell cycle distribution phases. Results are expressed as mean \pm SEM. ${ }^{\text {aa }}$ : significant difference from control group at $\mathrm{p}<0.01,{ }^{a}$ : significant difference from control group at $\mathrm{p}<0.05,{ }^{\mathrm{bbb}}$ : significant difference from PLN group at $\mathrm{p}<0.001,{ }^{\mathrm{bb}}$ : significant difference from PLN group at $\mathrm{p}<0.01$. 


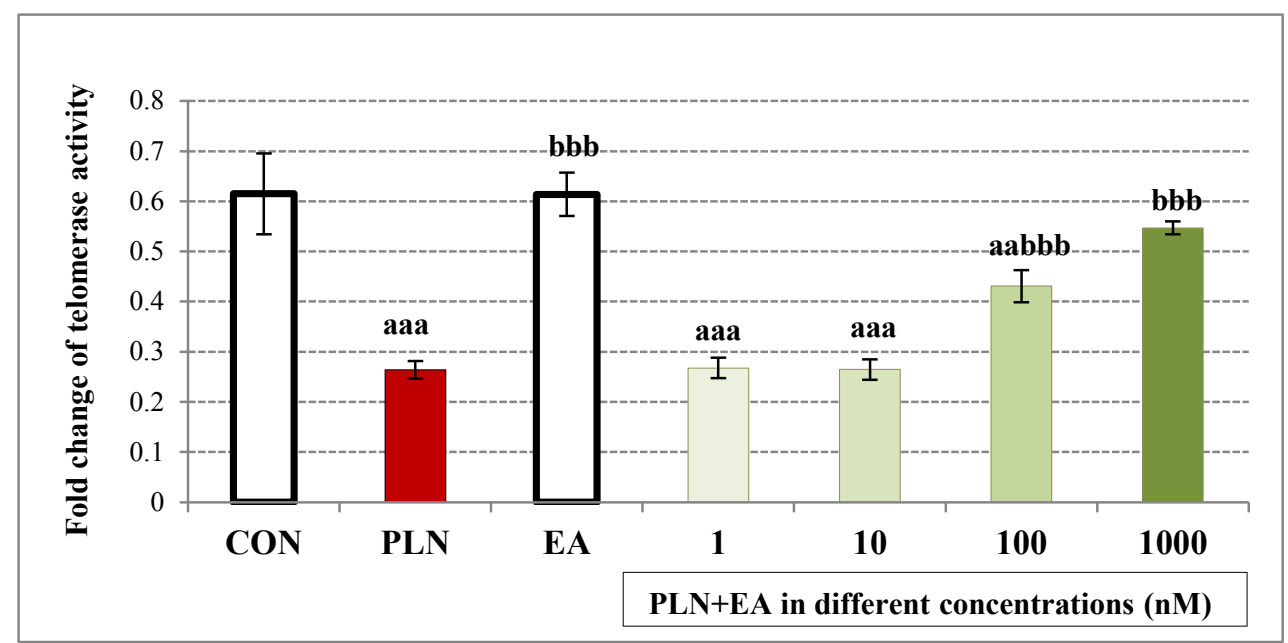

Fig. 12. Effect of PLN and various concentrations of EA on telomerase activity. Results are expressed as mean \pm SEM. ${ }^{\text {aaa }}$ : significant difference from control group at $\mathrm{p}<0.001$, ${ }^{\text {aa }}$ : significant difference from control group at $\mathrm{p}<0.01,{ }^{\mathrm{bbb}}$ : significant difference from PLN group at $\mathrm{p}<0.001$. 
Table 1. The abbreviations, accession numbers, and primers of proteins used for real time RTPCR.

\begin{tabular}{|l|c|c|l|}
\hline Gene name & Gene symbol & Accession no. & \multicolumn{1}{c|}{ Primer sequence (5'-3') } \\
\hline Retinoblastoma & Rb & NM_017045.1 & $\begin{array}{l}\text { F: CGGCAAATACAGAGACGCAA } \\
\text { R: TCTGGTCCAAATGTCGGTCT }\end{array}$ \\
Tumor protein p53 & $\mathrm{p} 53$ & NM_030989.3 & $\begin{array}{l}\text { F: ATCAAGAAAGTGGGGCCTGA } \\
\text { R: CAGAGACCCAGCAACTACCA }\end{array}$ \\
$\begin{array}{l}\text { Glyceraldehyde-3- } \\
\text { phosphate dehydrogenase }\end{array}$ & GAPDH & NM_017008.4 & $\begin{array}{l}\text { F: AGTCTACTGGCGTCTTCACC } \\
\text { R: CCACGATGCCAAAGTTGTCA }\end{array}$ \\
\hline
\end{tabular}


Table 2. Effect of PLN and various concentrations of EA on inflammatory cytokines (TNF- $\alpha$, IL-1 $\beta$, IL-6) and NF- $\kappa$ B level.

\begin{tabular}{|lcccc|}
\hline $\begin{array}{l}\text { Parameter/unit } \\
\text { (Mean } \pm \text { SE) }\end{array}$ & $\begin{array}{c}\text { TNF- } \alpha \\
\text { (pg/mg protein) }\end{array}$ & $\begin{array}{c}\text { IL-1 } \\
\text { (pg/mg protein) }\end{array}$ & $\begin{array}{c}\text { IL-6 } \\
\text { (pg/mg protein) }\end{array}$ & $\begin{array}{c}\text { NF-kB } \\
\text { (pg/mg protein) }\end{array}$ \\
\hline CON & $96.49 \pm 3.21$ & $86.99 \pm 3.35$ & $173.73 \pm 6.43$ & $15.97 \pm 0.29$ \\
PLN & $162.03 \pm 7.89^{\text {aaa }}$ & $143.30 \pm 5.47^{\text {aaa }}$ & $323.64 \pm 15.31^{\text {aaa }}$ & $32.51 \pm 1.0^{\text {aaa }}$ \\
EA & $91.22 \pm 2.59^{\text {bbb }}$ & $80.07 \pm 4.99^{\text {bb }}$ & $160.44 \pm 1.32^{\text {bbb }}$ & $15.99 \pm 0.42^{\text {bbb }}$ \\
PLN + EA1 & $147.82 \pm 2.36^{\text {aa }}$ & $131.97 \pm 3.03^{\text {aaa }}$ & $289.07 \pm 2.30^{\text {aaab }}$ & $22.06 \pm 0.65^{\text {aaa }}$ \\
PLN + EA10 & $131.52 \pm 2.76^{\text {aabb }}$ & $120.91 \pm 2.82^{\text {aaabb }}$ & $250.68 \pm 3.23^{\text {aaabbb }}$ & $21.65 \pm 0.56^{\text {aaa }}$ \\
PLN + EA100 & $128.1 \pm 1.45^{\text {aabb }}$ & $116.45 \pm 2.50^{\text {aabbb }}$ & $222.33 \pm 4.54^{\text {aabbb }}$ & $19.56 \pm 0.68^{\text {aabb }}$ \\
PLN + EA1000 & $108.94 \pm 3.63^{\text {bbb }}$ & $99.36 \pm 3.28^{\text {bbb }}$ & $182.98 \pm 6.74^{\text {bbb }}$ & $16.90 \pm 0.45^{\text {aabb }}$ \\
\hline
\end{tabular}

Results are expressed as mean \pm SEM. ${ }^{\text {aaa }}$ : significant difference from control group at $\mathrm{p}<0.001$, aa: significant difference from control group at $\mathrm{p}<0.01,{ }^{\text {bbb }}$ : significant difference from PLN group at $\mathrm{p}<0.001,{ }^{\mathrm{bb}}$ : significant difference from PLN group at $\mathrm{p}<0.01,{ }^{\mathrm{b}}$ : significant difference from PLN group at $\mathrm{p}<0.05$. 
Table 3. Relative mRNA expression using real-time PCR for expression of PLN and various concentrations of EA in REF cells compared to non-treated, control cells. GAPDH is the housekeeping gene control.

\begin{tabular}{|c|c|c|c|c|c|c|}
\hline \multicolumn{7}{|c|}{ Experimental groups (Relative fold change \pm SEM) } \\
\hline & & & PLN & + EA in differe & t concentrations & M) \\
\hline $\begin{array}{l}\text { Gene } \\
\text { symbol }\end{array}$ & PLN & EA & 1 & 10 & 100 & 1000 \\
\hline $\begin{array}{l}\text { p53 } \\
\text { Rb }\end{array}$ & $\begin{array}{l}7.27 \pm 0.07^{\text {aаa }} \\
5.74 \pm 0.10^{\text {aaa }}\end{array}$ & $\begin{array}{l}0.65 \pm 0.07^{\mathrm{bbb}} \\
0.57 \pm 0.11^{\mathrm{bbb}}\end{array}$ & $\begin{array}{c}7.01 \pm 0.10^{\text {aaa }} \\
3.78 \pm 0.14^{\text {aaabb }}\end{array}$ & $\begin{array}{c}6.71 \pm 0.54^{\text {aaa }} \\
3.30 \pm 0.22^{\text {aaabb }}\end{array}$ & $\begin{array}{l}4.13 \pm 0.11^{\text {aaabbb }} \\
2.14 \pm 0.04^{\text {aaabbb }}\end{array}$ & $\begin{array}{l}1.37 \pm 0.03^{\mathrm{bbb}} \\
1.72 \pm 0.02^{\mathrm{abbb}}\end{array}$ \\
\hline
\end{tabular}

Results are expressed as mean \pm SEM. ${ }^{\text {aaa }}$ : significant difference from control group at $\mathrm{p}<0.001$, a: significant difference from control group at $\mathrm{p}<0.05,{ }^{\mathrm{bbb}}$ : significant difference from PLN group at $\mathrm{p}<0.001,{ }^{\mathrm{bb}}$ : significant difference from PLN group at $\mathrm{p}<0.01$. 


\section{Phosalone (PLN)}<smiles>CCOP(=S)(OCC)SCn1c(=O)oc2cc(Cl)ccc21</smiles>

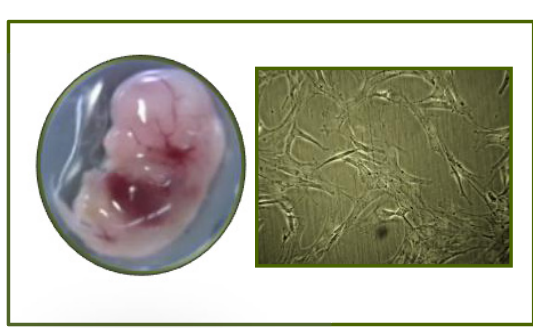

Rat Embryonic Fibroblasts (REFs)

\section{Ellagic acid (EA)}

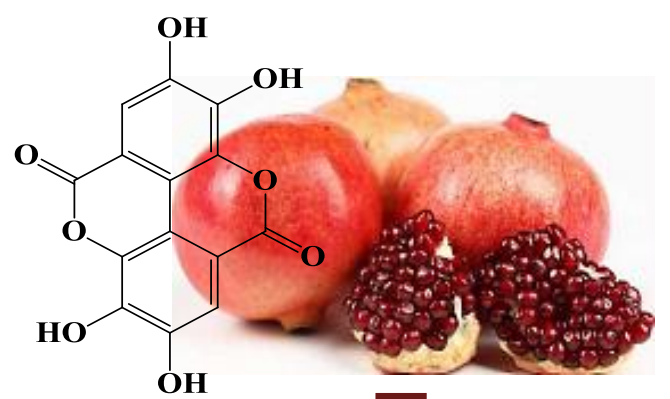

Dose-dependently deactivation of PLN-induced senescence in REFs

Suppression of PLN's toxicity through repression of P38, and P53 at the gene and protein levels

Promotion of cell viability and reduction of apoptosis

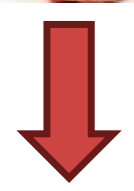

Cellular senescence

Oxidative stress and inflammation Telomerase enzyme activity

Cell cycle arrest at G0/G1

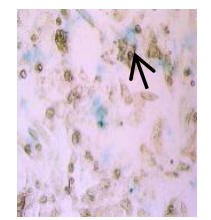

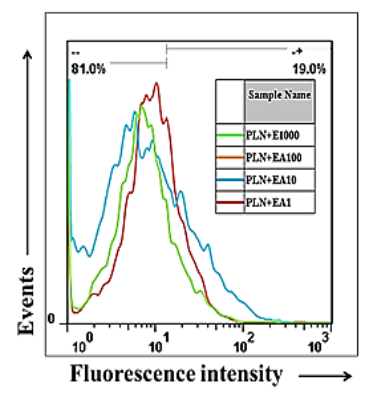

